(C) 2022, The Authors. Published by Elsevier Inc. and Fass Inc. on behalf of the American Dairy Science Association ${ }^{\circledR}$. This is an open access article under the CC BY license (http://creativecommons.org/licenses/by/4.0/).

\title{
Access time to pasture under wet soil conditions: Effects on productivity and profitability of pasture-based dairying
}

\author{
F. Fenger, ${ }^{1,2 *}$ (1. A. Casey, ${ }^{2} \odot$ N. M. Holden, ${ }^{3}$ and J. Humphreys ${ }^{1}$ \\ ${ }_{1}^{1}$ Animal and Grassland Research and Innovation Centre, Teagasc, Moorepark, Co. Cork, P61 P302, Ireland \\ ${ }^{2}$ Department of Chemical and Life Sciences, Waterford Institute of Technology, Waterford, X91 K0EK, Ireland \\ ${ }^{3}$ University College Dublin, School of Biosystems and Food Engineering, Agriculture and Food Science, Belfield, Dublin, D04 V1W8, Ireland
}

\begin{abstract}
A long grazing season improves the profitability of pasture-based dairy production. It can entail grazing under wet soil conditions and the risk of damaging swards. Housing cows either temporarily or completely while soil moisture is high can avoid damaging swards. An experiment with 4 grazing systems was conducted over 3 yr (Sep. 1, 2013, to Aug. 31, 2016). The purpose was to evaluate whether soil moisture measurements are an effective decision support to assess the risk of treading damage and effects on pasture productivity and dairy cow performance during wet soil conditions. Access time to pasture between February and December of each grazing season was dependent on volumetric soil moisture content (VSMC, $\mathrm{m}^{3} / \mathrm{m}^{3}$ ) measured each morning: Control $=$ cows were housed at VSMC $>0.5$ and otherwise allowed $22 \mathrm{~h} / \mathrm{d}$ access to pasture; $\mathrm{S}<7$ $=$ cows were housed on days with VSMC $>0.7$ and otherwise allowed $22 \mathrm{~h} / \mathrm{d}$ access to pasture; S7-6= cows were housed at VSMC $>0.7$ and allowed $8 \mathrm{~h} / \mathrm{d}$ access to pasture at VSMC between 0.7 and 0.6 and 22 $\mathrm{h} / \mathrm{d}$ access at VSMC $\leq 0.6 ; \mathrm{S} 7-5=$ cows were housed at VSMC $>0.7$ and allowed $8 \mathrm{~h} / \mathrm{d}$ access to pasture at VSMC between 0.7 and 0.5 and $22 \mathrm{~h} / \mathrm{d}$ access at VSMC $\leq 0.5$. Cows with 8 -h access per day received no other feeding when housed. All herds were compact spring-calving, with a mean calving date of Feb. 19. Mean stocking rate was 2.57 cows/ha. Measurements of VSMC provided an objective indicator for the risk of treading damage. Less time spent at pasture under wet soil conditions lowered treading damage but had no effect on annual pasture production (mean $14.8 \mathrm{t}$ of organic matter/ha). Annual milk solids production per cow was lowest for the control herd $(485 \mathrm{~kg})$ and not different between the other systems $(503 \mathrm{~kg})$. Reducing treading damage to swards did not improve productiv-
\end{abstract}

Received May 17, 2021.

Accepted January 7, 2022.

*Corresponding author: friederike.fenger@postgrad.wit.ie ity or profitability of the grazing systems. Nevertheless, measuring soil moisture was a useful decision support for assessing the risk of treading damage when turning cows out to pasture.

Key words: grazing management, pasture-based dairy production, restricted access, treading damage

\section{INTRODUCTION}

A long grazing season improves the profitability of pasture-based dairy production (Läpple et al., 2012; Hanrahan et al., 2018). However, grazing dairy cows, particularly during the winter, spring, and autumn, can damage both the sward and upper soil layers, which can lower pasture production (Pietola et al., 2005; Drewry et al., 2008; Phelan et al., 2013; Tuñon et al., 2014). Creighton et al. (2011) showed that $60 \%$ of Irish dairy farmers identified wet soil conditions as the most important factor influencing their decision whether or not to turn livestock out to pasture. Treading damage by the hooves of grazing animals, which is a plastic deformation of the soil surface, is most likely to occur under wet soil conditions (Drewry et al., 2008; Phelan et al., 2013). At higher latitudes of the temperate zones, soil moisture content is typically highest during the winter, spring, and autumn due to seasonally higher rainfall combined with low evapotranspiration. To achieve a long grazing season, it is often necessary to turn cows out to pasture under less-than-optimal soil moisture conditions.

Keeping cows indoors to avoid treading damage on farms on poorly drained soils shortens the grazing season and increases the cost of production compared with farms situated on well-drained soils (Shalloo et al., 2004; Fitzgerald et al., 2008; Hanrahan et al., 2018). Restricting the time that cows have access to pasture per day to short grazing bouts is one way of incorporating more grazed pasture in the diet while limiting treading damage. Typically, cows are allowed access to pasture for 2 grazing bouts per day, each of 3 to $4 \mathrm{~h}$ in duration. Cows are housed or held on a standoff pad for the remainder of each day and often receive no 
additional feed during this time. Such an approach has been shown to maintain pasture intake and milk production (Gregorini et al., 2009; Kennedy et al., 2009; Pérez-Ramírez et al., 2009), cause less damage to soil structure (Houlbrooke et al., 2009; Laurenson et al., 2016), and lower the risk of nutrient losses to water (Clark et al., 2010; Christensen et al., 2019).

Although many studies have measured the effects of treading on soil structure and pasture production, the extent of treading is typically ascertained after the grazing event (Houlbrooke et al., 2009; Phelan et al., 2013; Tuñon et al., 2014; Laurenson et al., 2016). From a commercial farming perspective, the concern is to prevent treading damage before it happens, because it is likely to be detrimental to current and future productivity of pastures and to the dairy cows. This requires the capacity to ascertain the soil moisture conditions that are not suitable for grazing in advance of the grazing event. Indeed, we are not aware of any unambiguous and objective definition of suboptimal conditions for grazing that can be used as on-farm decision support. Hence, the overall objective of the present study was to ascertain how soil moisture, measured using a soil probe at a central location on a farm, can be used to support the decision to (1) keep cows indoors, (2) allow cows restricted access to pasture for a few hours per day, or (3) allow cows out to pasture for most of the day, on days of the year when conditions are typically considered suboptimal for grazing. Ultimately, a decision support system should improve profitability or increase environmental sustainability of a production system. Hence, the present study was designed to simultaneously assess the effects of different grazing management strategies on the profitability of dairy production. Earlier studies at the same site as that of the present study (Phelan et al., 2013; Tuohy et al., 2015) have shown that soil moisture can be above the plastic limit, which indicates the onset of possible treading damage, during much of the grazing season. Hence, a certain degree of treading damage throughout the grazing season is unavoidable at this site. Nevertheless, using the results of these 2 earlier studies (Phelan et al., 2013; Tuohy et al., 2015), it was determined that there was a low risk of treading damage at a volumetric soil moisture content (VSMC, $\mathrm{m}^{3} / \mathrm{m}^{3}$ ) of $<0.5$, and severe treading damage was likely at VSMC $>0.7$. Hence, 4 grazing systems were established, one with a low risk of treading damage and one that entailed a high risk of damage at risky times of the year. The other 2 systems were designed to examine the practice of restricting daily access time to pasture under different criteria of VSMC as a means of curtailing damage to paddocks and potentially increasing pasture production.

\section{MATERIALS AND METHODS}

\section{Site Description}

The experiment was conducted at Solohead Research Farm $\left(52^{\circ} 30^{\prime} \mathrm{N}, 08^{\circ} 12^{\prime} \mathrm{W}, 95 \mathrm{~m}\right.$ above sea level) in southwest Ireland. Soils at the farm include poorly drained Gleysols (90\%) and Podzols (10\%) with a clay loam texture (36\% sand and $28 \%$ clay) in the A1 horizon overlaying Devonian sandstone at a depth of 5 to 10 $\mathrm{m}$ below ground level (FAO, 2015). Topographic relief causes variation in shallow groundwater, with the water table depth ranging from 0 to $2.2 \mathrm{~m}$ below ground level. Much of the farm area is seasonally wet, waterlogged, or flooded. The local climate is humid temperate oceanic, with a long potential growing season $(\sim 10$ mo). The land has been under permanent grassland with predominantly perennial ryegrass and white clover swards for well over $50 \mathrm{yr}$, and approximately $5 \%$ of the grassland was renovated each year.

\section{Experimental Systems}

Ethical approval for this study was deemed not necessary because animals were handled and treated as in a normal commercial farm operation. The experiment was carried out over 3 consecutive years: from Sep. 1, 2013, to Aug. 31, 2016, with each year spanning the timeframe between Sep. 1 and Aug. 31. Four grazing systems were established, where daily measured VSMC was used to determine (1) when (days per year) lactating cows were allowed access to pasture and (2) the length of time per day that cows were allowed access to pasture in each of the 4 systems (Table 1 ). These access times ranged from entailing a very low risk of treading damage (control) to a high risk of damage $(\mathbf{S}<\mathbf{7})$. The control system was designed to reflect the cautious management practice prevalent on many Irish dairy farms. Management similar to that in $\mathrm{S}<7$ is practiced rarely on Irish dairy farms and was designed to represent extreme management practices. The other 2 systems ( $\mathbf{S 7}-\mathbf{6}$ and $\mathbf{S 7}-\mathbf{5})$ were intermediate in terms of treading risk and involved allowing the herds restricted access to pasture on the days that they were allowed out to pasture. These 2 systems were designed to represent recommended best practices, which involve restricted daily access time under wet soil conditions and periods of heavy rainfall (Kennedy et al., 2016).

At VSMC $\leq 0.7$, cows in $\mathrm{S}<7$ were allowed out to pasture for the entire day, excluding milking times in the morning and evening, with milking times accounting for approximately $2 \mathrm{~h}$ per day. When VSMC $>0.7$ the $\mathrm{S}<7$ herd was housed. Likewise, the control herd was 
Table 1. Daily access to pasture (h) for cows according to volumetric soil moisture content (VSMC, $\mathrm{m}^{3} / \mathrm{m}^{3}$ ) and number of hours per day that lactating cows in the 4 grazing systems were allowed access to pasture

\begin{tabular}{lcccc}
\hline & \multicolumn{4}{c}{ Grazing system } \\
\cline { 2 - 5 } VSMC & $\mathrm{S}<7$ & $\mathrm{~S} 7-6$ & $\mathrm{~S} 7-5$ & Control \\
\hline$>0.7$ & 0 & 0 & 0 & 0 \\
$0.7-0.6$ & 22 & 8 & 8 & 0 \\
$0.6-0.5$ & 22 & 22 & 8 & 0 \\
$\leq 0.5$ & 22 & 22 & 22 & 22 \\
\hline
\end{tabular}

housed when VSMC $>0.5$ and allowed $22 \mathrm{~h}$ per day access to pasture once VSMC $\leq 0.5$. Restricted access per day involved a 4 -h grazing bout immediately after the morning milking and a 4 -h grazing bout immediately after the evening milking, as recommended by Kennedy et al. (2009). Herds were housed once the allotted time had elapsed. During the days that cows were allowed 8-h access to pasture, they received no other additional feeding when housed; that is, their entire diet was grazed pasture, as recommended by Kennedy et al. (2011). The S7-6 herd was housed when VSMC >0.7, was allowed 8-h access to pasture per day when VSMC was between 0.7 and 0.6 , and was allowed 22 -h access to pasture per day when VSMC $\leq 0.6$. Likewise, the S7-5 herd was housed when VSMC $>0.7$, was allowed 8-h access to pasture per day when VSMC was between 0.7 and 0.5 , and was allowed 22-h access to pasture per day when VSMC $\leq 0.5$ (Table 1 ). On days that a herd was housed full time, that herd received silage (ensiled pasture) ad libitum.

The only exception to these management rules was when pasture mass was too low to sustain herd demand, which occurred when pasture growth rates were below herd demand and pre-grazing pasture mass was $<1,000 \mathrm{~kg}$ of $\mathrm{DM} / \mathrm{ha}$ (measured to $4 \mathrm{~cm}$ above ground level). Under such circumstances, cows were housed and received silage ad libitum, and were occasionally supplemented with concentrates according to the feed budget for each herd (see below). All silage fed during the experiment was harvested from the experimental area. Energy content of the concentrate feed $(35 \%$ beet pulp, $26 \%$ barley, $26 \%$ maize gluten, and $12 \%$ soybean meal) was 0.95 UFL (unité fourragère laitière).

Additional to the management rules outlined here and in Table 1, the end of the grazing season (cows housed for the winter; Table 2) was determined by an average pasture mass of $500 \mathrm{~kg}$ of DM/ha across all the paddocks in each system.

Table 2. Details of the grazing systems imposed during the $3 \mathrm{yr}$ of the experiment (Sep. 1, 2013, to Aug. 31, 2016)

\begin{tabular}{|c|c|c|c|c|c|}
\hline \multirow[b]{2}{*}{ Item } & \multicolumn{4}{|c|}{ Grazing system ${ }^{1}$} & \multirow[b]{2}{*}{ SEM } \\
\hline & $\mathrm{S}<7$ & S7-6 & $\mathrm{S} 7-5$ & Control & \\
\hline End of grazing season 2013 & 19 Nov & $19 \mathrm{Nov}$ & 07 Dec & 13 Dec & \\
\hline End of grazing season 2014 & $22 \mathrm{Nov}$ & $22 \mathrm{Nov}$ & 22 Nov & 06 Nov & \\
\hline End of grazing season 2015 & 29 Nov & $29 \mathrm{Nov}$ & 29 Nov & 08 Nov & \\
\hline Start of grazing season 2014 & $24 \mathrm{Feb}$ & $24 \mathrm{Feb}$ & $24 \mathrm{Feb}$ & 04 Mar & \\
\hline Start of grazing season 2015 & 17 Feb & $17 \mathrm{Feb}$ & $17 \mathrm{Feb}$ & 20 Mar & \\
\hline Start of grazing season 2016 & $08 \mathrm{Feb}$ & $08 \mathrm{Feb}$ & $08 \mathrm{Feb}$ & 16 Mar & \\
\hline Overall stocking rate $^{2}$ (cows/ha) & 2.57 & 2.57 & 2.57 & 2.57 & \\
\hline \multicolumn{6}{|l|}{$\begin{array}{l}\text { Monthly stocking rates when areas } \\
\text { closed for silage were accounted for } \\
\text { (cows/ha) }\end{array}$} \\
\hline September to December & 2.57 & 2.57 & 2.57 & 2.57 & $0.06^{\mathrm{NS}}$ \\
\hline February to March & 2.60 & 2.60 & 2.60 & 2.62 & $0.03^{\mathrm{NS}}$ \\
\hline April to June & $3.92^{\mathrm{b}}$ & $3.81^{\mathrm{b}}$ & $3.87^{\mathrm{b}}$ & $4.65^{\mathrm{a}}$ & $0.14^{*}$ \\
\hline July to August & 3.21 & 3.16 & 3.19 & 3.49 & $0.14^{\mathrm{NS}}$ \\
\hline Mean & $3.03^{\mathrm{b}}$ & $2.99^{\mathrm{b}}$ & $3.02^{\mathrm{b}}$ & $3.29^{\mathrm{a}}$ & $0.05^{* * *}$ \\
\hline \multicolumn{6}{|c|}{ Proportion of area harvested for silage } \\
\hline April to June & 0.42 & 0.46 & 0.45 & 0.67 & $0.07^{\mathrm{NS}}$ \\
\hline July to mid-August & 0.37 & 0.40 & 0.32 & 0.53 & $0.07^{\mathrm{NS}}$ \\
\hline
\end{tabular}

${ }^{\mathrm{a}, \mathrm{b}}$ Mean values in the same row with different superscripts differ between grazing systems $(P<0.05)$.

${ }^{1} \mathrm{~S}<7$ : cows were housed on days with VSMC $>0.7$ and otherwise allowed $22 \mathrm{~h} / \mathrm{d}$ access to pasture; $\mathrm{S} 7-6=$ cows were housed at VSMC $>0.7$ and allowed $8 \mathrm{~h} / \mathrm{d}$ access to pasture at VSMC between 0.7 and 0.6 and 22 $\mathrm{h} / \mathrm{d}$ access at VSMC $\leq 0.6 ; \mathrm{S} 7-5=$ cows were housed at VSMC $>0.7$ and allowed $8 \mathrm{~h} / \mathrm{d}$ access to pasture at VSMC between 0.7 and 0.5 and $22 \mathrm{~h} / \mathrm{d}$ access at VSMC $\leq 0.5$; control $=$ cows were housed at VSMC $>0.5$ and otherwise allowed $22 \mathrm{~h} / \mathrm{d}$ access to pasture (see Table 1 for further description).

${ }^{2}$ On overall farm area.

${ }^{*} P<0.05,{ }^{* * *} P<0.001,{ }^{\mathrm{NS}} P>0.05$ (not significant). 


\section{Experimental Set Up and Design}

All cows used in the experiment were compact springcalving, with a mean calving date of Feb. 19. In 2013 all cows were managed as a single herd before the beginning of the experiment. In August 2013 all cows were divided into 4 main groups based on lactation number $(1,2,3$, and $\geq 4)$ and then subdivided into subgroups of 4 on the basis of calving date. One cow from each subgroup was randomly assigned to each herd. Herds were randomly assigned to each grazing system. In the spring of 2014, 2015, and 2016, cows were assigned to herds and herds to grazing systems in the same manner as described herein. Mean overall stocking rate on each system was 2.57 cows/ha (Table 2). There were 23 cows per herd in 2013/14 (year 1 ), 25 cows per herd in 2014/15 (year 2), and 24 cows per herd in 2015/16 (year 3). Annual milk data for each experimental year encompassed Sep. 1, 2013, to Aug. 31, 2014 (year 1); Sep. 1, 2014, to Aug. 31, 2015 (year 2); and Sep. 1, 2015, to Aug. 31, 2016 (year 3).

Cows were turned out to pasture approximately 3 $\mathrm{d}$ after calving and dried off in late November and December. Only lactating cows were allowed out to pasture. Nonlactating cows were kept indoors before calving in spring and after the end of lactation. Cows that calved before turnout (start of the grazing season) were kept indoors and fed silage ad libitum. In early lactation (February to April), cows received up to $6 \mathrm{~kg}$ of concentrate per cow per day, depending on the mass of pasture available on the grazing area. During the rest of the grazing season (from May onward) between 0 to $2 \mathrm{~kg}$ of concentrate was fed per cow per day. Daily concentrate supplementation per cow was the same across all systems.

The experimental area was divided into 6 blocks based on soil type and drainage status in August 2013. Each block was divided into 4 paddocks. One paddock from each block was randomly assigned to each system and remained in that system until the end of the experiment, resulting in 6 paddocks per system (9.35 ha per system). Strip-grazing management was practiced in all systems. Excess pasture mass per system was identified and removed as silage throughout the grazing season. This was generally the case when pasture growth rate was higher than the feed demand of the grazing herd, resulting in pre-grazing pasture masses $>1,600 \mathrm{~kg}$ of $\mathrm{DM} / \mathrm{ha}$ between April and July, and $>2,000 \mathrm{~kg}$ of DM/ ha from August onward. The proportion of the area that was closed for silage in each system is presented in Table 2. Each system received annual nitrogen input of $280 \mathrm{~kg}$ of N/ha in the form of mineral fertilizer and 56 $\mathrm{kg}$ of $\mathrm{N} / \mathrm{ha}$ in the form of cattle slurry, which is in line with national guidelines (DAFM, 2020). Mineral nitrogen fertilizer was applied in the form of urea between February and April and in the form of calcium ammonium nitrate between May and September, distributed over the course of the growing season in line with sward requirements.

\section{Measurements}

Meteorological Data. Soil temperature $\left({ }^{\circ} \mathrm{C}\right.$, at soil depth of $10 \mathrm{~cm})$, rainfall $(\mathrm{mm})$, wind speed $(\mathrm{m} / \mathrm{s})$ and direction $\left({ }^{\circ}\right)$, and solar radiation $(\mathrm{J} / \mathrm{cm})$ were measured at an automated weather station on the research farm. Volumetric soil moisture content $\left(\mathrm{m}^{3} / \mathrm{m}^{3}\right)$ was measured daily at the weather station in the upper $5 \mathrm{~cm}$ of the soil (Gleysol) using an ML2x Soil Moisture Measurement Kit (Delta-T Devices Ltd.). Fully screened piezometers (high-density polyethylene pipes, internal diameter $19.6 \mathrm{~cm}$; Eijkelkamp, Agrisearch Equipment) were installed to a depth of $2 \mathrm{~m}$ in each paddock before the beginning of the experiment. Groundwater table depth (WTD; m below soil surface) was measured every week during the experiment using a Geosense electric water level meter with acoustic signal (Marton Geotechnical Services Ltd.). Daily weather data (rainfall, temperature, wind speed, and solar radiation) were used to calculate soil moisture deficit for each day of the experiment using the model of Schulte et al. (2005) and assuming a moderately drained soil.

Time at Pasture. The length of the grazing season was measured in terms of days at pasture per cow, where each day was where cows were allowed access to pasture for either $22 \mathrm{~h}$ or $8 \mathrm{~h}$. The number of days with $22 \mathrm{~h}$ and $8 \mathrm{~h}$ at pasture per cow were recorded separately. Annual time at pasture (h/cow) was calculated for each cow based on records of days at pasture, as described previously. The proportion of lactating cows at pasture and dry cows indoors was considered when accounting for both the annual number of days at pasture and the annual number of hours at pasture per cow.

Treading Damage. Soil surface deformation and hoofprint depth were recorded after a grazing event in each grazing system once per week during the grazing season. Soil surface deformation $(\mathrm{cm} / \mathrm{m})$ was measured using a link chain attached to one end of a straight wooden pole. Both the chain and pole were $2 \mathrm{~m}$ in length. The pole and chain were laid horizontally on the soil surface, and the chain was fitted to the contours of the soil. Surface deformation was quantified as the reduction in chain length $(\mathrm{cm})$ relative to the length of the wooden pole. A greater reduction in chain length represented greater damage. Measurements were made at 30 locations selected at random in each pad- 
dock. The depth of hoofprints $(\mathrm{cm})$ was measured with calipers at 100 random locations across the paddock.

Pasture Production, Utilization, and Nutritive Value of the Sward. Before each grazing event, pregrazing pasture mass was determined by harvesting a strip $(1.2 \times 10 \mathrm{~m})$ of pasture using an Etesia Hydro 124DS Lawnmower (Etesia UK Ltd.) set at a cutting height of $4 \mathrm{~cm}$ above ground level. All mown pasture was collected and weighed. A 100-g (fresh weight) subsample was dried for $16 \mathrm{~h}$ at $90^{\circ} \mathrm{C}$ for determination of DM content, which was then used for determination of pre-grazing pasture mass ( $\mathrm{kg}$ of $\mathrm{DM} / \mathrm{ha})$. Pasture masses of harvests for silage were determined likewise.

A second 100-g subsample was freeze-dried and milled through a $0.2-\mathrm{mm}$ sieve before analyses for ash content $\left(550^{\circ} \mathrm{C}\right.$ muffle furnace for $\left.12 \mathrm{~h}\right)$, $\mathrm{CP}$ (N content; Leco 528 Auto-Analyzer, Leco Corp.), NDF (Van Soest, 1990), and in vitro OM digestibility as described by Morgan et al. (1989).

Due to contamination of samples during the harvesting process in wet soil conditions, ash contents during spring were higher than usual. Hence, annual pasture masses are presented as OM, and ash contents are not presented. Total annual pasture production ( $\mathrm{t}$ of $\mathrm{OM} /$ ha) for each paddock was determined as the sum of pasture mass removed as pre-grazing and pre-silage cuts.

Post-grazing sward height $(\mathrm{cm})$ on each system was estimated using a rising plate meter (Grasstec) approximately once per week immediately after a grazing event. Pasture mass available for grazing in each system was measured typically once per week during the grazing season. On each occasion, compressed sward height was recorded on each paddock, which was converted into pasture cover, an estimate of pasture mass DM 4 $\mathrm{cm}$ above ground level, using a sward density of $240 \mathrm{~kg}$ of $\mathrm{DM} / \mathrm{cm} / \mathrm{ha}$.

Feed Intake and Milk Production. The amount of concentrate fed per cow was recorded at each milking (Dairymaster). Silage bales were opened up and offered to cows at the feed-barrier. Silage intake was estimated as silage fed to cows; that is, the difference between what was offered and what was discarded. Sample bales of silage and discards were weighed on a weekly basis using a weighing scale and the Winweigh software package (Tru-Test Limited). On each occasion a grab sample from each bale was collected, and 100 $\mathrm{g}$ (fresh weight) of subsample was dried for $16 \mathrm{~h}$ at $90^{\circ} \mathrm{C}$ for determination of $\mathrm{DM}$ content, which was then used to determine the dry weight of each silage bale. Approximately once per month a second subsample (n = 33) was analyzed for ash, DM digestibility, NDF, and CP, using laboratory techniques similar to those described previously.
Intake of grazed pasture for each cow was estimated as the difference between net energy provided from silage and concentrates and the net energy requirements for milk production, maintenance, and pregnancy (Jarrige et al., 1986; Jarrige, 1989; O'Mara, 1996). Requirements for activity and walking were included in requirements for maintenance as an increase of $10 \%$ for each day indoors and $20 \%$ for each day at pasture (22-h and 8-h access to pasture).

Cows were milked at 0730 and 1530 h daily throughout lactation. Milk yield from each cow was recorded at each milking, and milk composition was measured twice weekly from the morning and evening milking using a Milkoscan 203 (Foss Electric). The liveweight of each cow was recorded at 2-wk intervals throughout each year using a weighing scale and the Winweigh software package (Tru-Test Limited). Body condition score (Edmonson et al., 1989) of each cow was recorded at 2-wk intervals throughout each year.

\section{Economic Analysis}

Profitability of each grazing system was determined using a whole-farm spreadsheet model similar to that described by Humphreys et al. (2012). The biological data of each system from each year were used, taking into account the statistical analysis of the data; where no statistical difference occurred between systems within a year, the mean of the systems was used in the economic analysis to ensure that differences caused by residual errors did not lead to differences in profitability. Grazing systems were compared on the basis of a farm area of 50 ha stocked at 2.5 cows/ha. Replacement heifer calves were transferred to be reared on another farm on contract at approximately 3 wk of age. Dairy replacements were reared at a total cost of €947 per animal, based on a cost of $€ 1.30$ per day per animal (Teagasc, 2013a). Likewise, surplus calves were sold at approximately 3 wk of age for $€ 250$ per female calf and $€ 50$ per male calf. Culled cows were sold off the farm at the end of lactation in December at $€ 550$ per cow. The dairy cow replacement rate in all systems was $21 \%$. Silage was produced on the farm to meet winter feed requirements. Surpluses of silage were sold each year, and deficits were met by purchased silage at $€ 130$ per tonne of DM. Surpluses and deficits were calculated as the difference between preserved and consumed silage per system.

Basic annual labor requirement for all systems was set as $26.7 \mathrm{~h} /$ cow, the national average of spring-calving pasture-based dairy farms in Ireland (Donnellan et al., 2020). Grazing system $S<7$ was considered to have the lowest requirements for labor, with only the basic an- 
nual labor per cow. Systems S7-6, S7-5, and control all had additional requirements for labor. For each day that cows had 8-h access to pasture and needed more management, bringing cows from field to house to milking shed (compared with from field to milking shed under 22-h access to pasture) increased labor requirements by $1 \mathrm{~h}$ per day. In addition, labor requirements increased by $2 \mathrm{~h}$ per day for each additional day that cows were housed, compared with cows in $\mathrm{S}<7$, and needed more management; that is, feeding of grass silage and manure (slurry) management (compared with no feeding under 22 -h access to pasture). The amount of slurry produced in each grazing system was calculated based on time spent indoors; that is, hours of the year minus annual time at pasture $(\mathrm{h} / \mathrm{cow})$, with $0.06 \mathrm{~m}^{3}$ slurry produced per cow per $24 \mathrm{~h}$ indoors (Teagasc, 2013b).

For economic interpretation of the experimental data, secondary data resources were used for input and output prices, such as the Central Statistics Office of Ireland (CSO, 2020), Teagasc National Farm Survey (Donnellan et al., 2020), Teagasc Management Data for Farm Planning (Teagasc, 2013b), and Contracting Charges Guide (FCI, 2019; Table 3). Estimates for fixed costs were taken from the results of the Teagasc National Farm survey (Donnellan et al., 2020) due to unavailability of representative fixed costs for the systems. A cost of $€ 858 /$ ha on the basis of each hectare of the farm area was used for each grazing system, which included the costs of car, electricity, phone, interest (financial), machinery use and depreciation, building maintenance and depreciation, land improvement maintenance and depreciation, and other miscellaneous fixed costs, such as insurance, advisory fees, and others.

Profitability was expressed as net profit, which was calculated as total receipts (milk, livestock) less variable (feed, fertilizer, veterinary, artificial insemination, and contractor charges) and fixed costs (as outlined previously). No farm subsidy payments were included in the calculation. All land was considered to be owned. Opportunity costs of land were included as the difference between the returns on the best forgone option

Table 3. Economic data used in the economic assessment of the 4 grazing systems

\begin{tabular}{lc}
\hline Item & Value \\
\hline Concentrate feed $(€ / \mathrm{t})$ & 280 \\
Fertilizer urea $(€ / \mathrm{t})$ & 360 \\
Fertilizer calcium ammonium nitrate $(€ / \mathrm{t})$ & 260 \\
Labor $(€ / \mathrm{h})$ & 15 \\
Veterinary and artificial insemination $(€ /$ cow $)$ & 90 \\
Silage harvest $(€ /$ bale $)$ & 20 \\
Slurry spreading $(€ / \mathrm{h})$ & 65 \\
Fertilizer spreading $(€ / \mathrm{t})$ & 37 \\
\hline
\end{tabular}

and the returns on the chosen option. The current land rental price ( $€ 450 /$ ha; Coulter et al., 2020) was defined as the best forgone option. If net profit per hectare (returns on chosen option) was lower than land rental price (returns on best forgone option), the difference was applied as opportunity costs. In this way, opportunity costs of land represented the cost of not choosing the better alternative.

The analysis was conducted at a base milk price of $€ 0.29 / \mathrm{L}$ with a reference content of $33 \mathrm{~g} / \mathrm{kg}$ of milk protein and $36 \mathrm{~g} / \mathrm{kg}$ of milk fat at a relative price ratio of 1:1.5 (fat:protein) in a multiple component payment system (A + B - C; Geary et al., 2010).

\section{Statistical Analysis}

All results were subjected to ANOVA using the MIXED procedure in SAS 9.4 (SAS Institute Inc., 2014). For analysis of annual means, grazing system was a fixed effect, and year and block were random effects in the ANOVA. Experimental year was considered a random effect, as the environmental conditions were assumed to vary randomly from year to year and differences in rainfall and soil moisture status between years were small. All annual data (time at pasture, treading damage, pasture production, feed intake, milk production, and economic performance) for each experimental year (2013/14, 2014/15, and 2015/16) encompassed Sep. 1 to Dec. 31 of the first year and Jan. 1 to Aug. 31 of the following year: Sep. 1, 2013, to Aug. 31, 2014, in yr $1(2013 / 14)$; Sep. 1, 2014, to Aug. 31, 2015, in yr 2 (2014/15); and Sep. 1, 2015, to Aug. 31, 2016, in yr $3(2015 / 16)$.

Individual cows were experimental units for animalrelated variables. For animal-related variables, block numbers were used to join data across calendar years to create annual means for each of the experimental years; that is, data for the cow in block 1 between Sep. 1 and Dec. 31 were joined with data for the cow in block 1 between Jan. 1 and Aug. 31 of the following calendar year. Because the cows were assigned to blocks in the same way each year, as described previously, this method ensured that the lactation number and approximate calving date were the same for each cow in each of the blocks that were joined. Individual paddocks were experimental units for field-based variables. The same paddocks and blocks were used in all experimental years, as paddocks remained in the same system until the end of the experiment.

For measurements that were calculated on system basis, year was used as the replicate: pasture mass harvested as pre-silage or pre-grazing cuts and profitability of the systems. Simple relationships between 
(a)

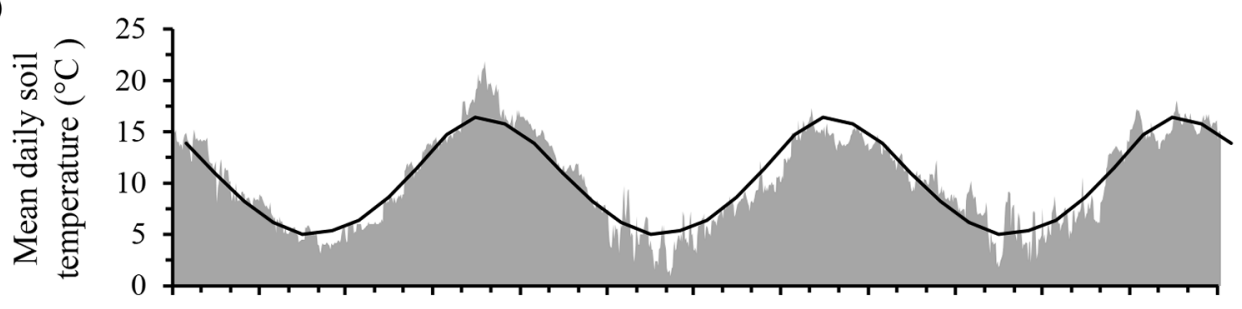

(b)

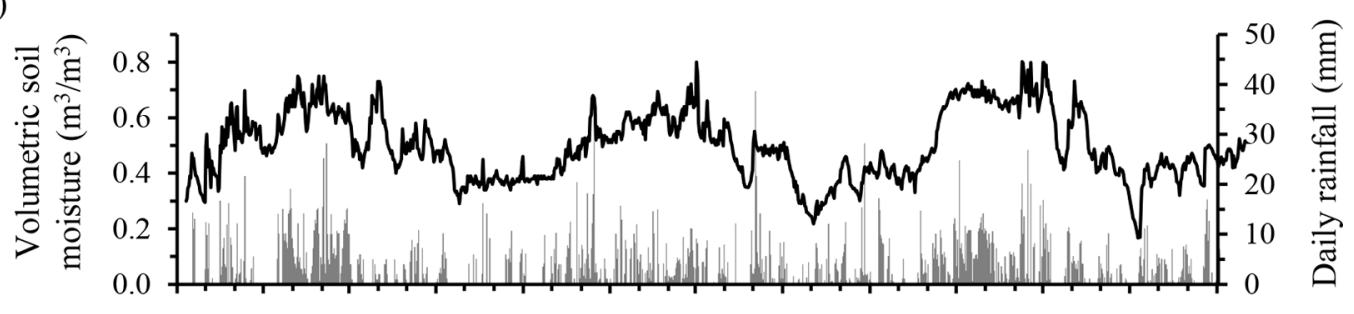

(c)

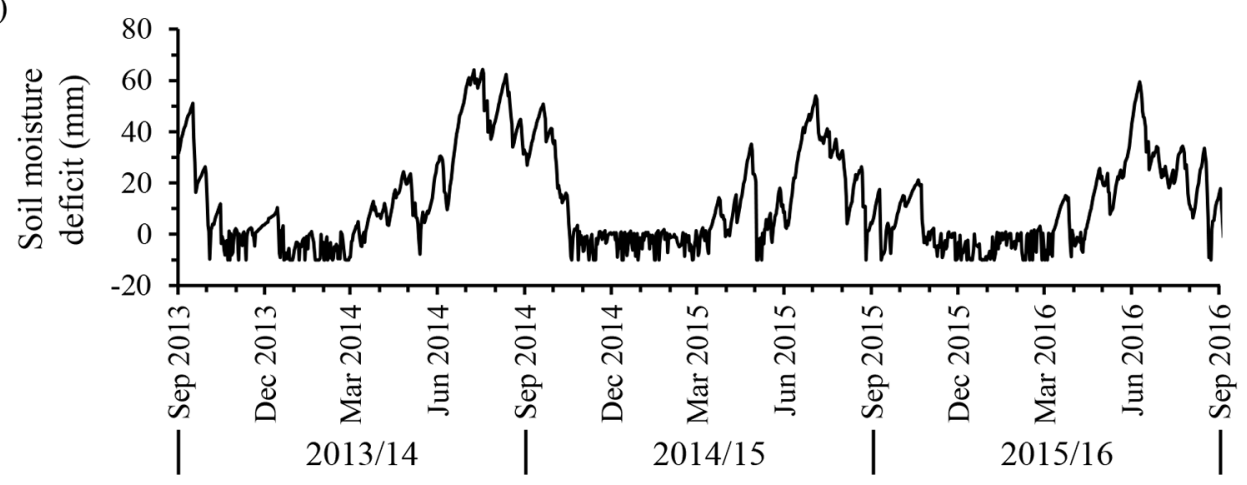

Figure 1. (a) Mean daily soil temperature $\left({ }^{\circ} \mathrm{C}\right.$, at a soil depth of $10 \mathrm{~cm}$ ) during the experimental period (gray area) compared with 15 -yr average (solid line); (b) volumetric soil moisture content $\left(\mathrm{m}^{3} / \mathrm{m}^{3}\right.$, solid line), daily rainfall (mm, gray bars), and (c) soil moisture deficit (mm) during the experimental period.

values were analyzed using correlation analysis (Pearson correlation coefficient) in the CORR procedure and regression analysis in the GLM procedure. Means are presented as least squares means \pm standard error of the mean (SEM).

\section{RESULTS}

\section{Rainfall and Soil Moisture Status}

Soil temperatures were close to the long-term average during most of the experiment. Only between June and September of 2013/14 soil temperatures were considerably above average (Figure 1a). Annual rainfall was $1,162 \mathrm{~mm}$ in $2013 / 14,1,093 \mathrm{~mm}$ in $2014 / 15$, and 1,320 $\mathrm{mm}$ in $2015 / 16$. The mean of the previous $15-\mathrm{yr}$ period was 1,056 mm. Rainfall in spring (March-May) of $2014 / 15$ and $2015 / 16$ was above the 15-yr mean (263 and 233 vs. $201 \mathrm{~mm}$, respectively). All 3 experimental years had below-average rainfall in summer (June-August: 154, 203, and 237 vs. $240 \mathrm{~mm}$ ) and autumn (September-November: 241, 296, and 277 vs. $325 \mathrm{~mm}$ ) and above-average rainfall in winter (December-February: 595, 330, and 572 vs. $289 \mathrm{~mm}$ ). During the main grazing season (April-October) VSMC exceeded 0.6 only once, in April 2016. Values between 0.5 and 0.6 were measured mainly between October and the following May. Values $>0.7$ occurred primarily between December and March and on $4 \mathrm{~d}$ in early April 2014. In 2013/14, rainfall was low during November and December, resulting in a VSMC below 0.5 for $15 \mathrm{~d}$ in December 2013 (Figure 1b). Mean annual soil moisture deficits were 15, 12, and $9 \mathrm{~mm}$ in 2013/14, 2014/15, and 2015/16, respectively. Saturated soil conditions (soil moisture deficit $=-10 \mathrm{~mm}$ ) occurred on 24,17 , and $22 \mathrm{~d} / \mathrm{yr}$ in each of the 3 experimental years, respectively (Figure 1c). We observed a clear seasonal trend in WTD, with the lowest WTD in September of each year (Figure 2). 


\section{Time at Pasture}

The grazing season ended earlier and started later in control compared with the other 3 systems (Table 2). An exception was in 2013/14, when control and S7-5 were allowed out to graze due to the low VSMC during December 2013. Averaged over 3 experimental years, cows on the control system spent $206 \mathrm{~d}$ at pasture per year, which was lower $(P<0.001)$ than the cows on $\mathrm{S}<7$, S7-6, and S7-5 (mean 259 d; SEM 1.64, which included both 22 -h and 8 -h days at pasture). The average number of days per year when cows had 8-h access to pasture was 30 on S7-6 and 51 on S7-5. Mean annual time at pasture was $5,696(\mathrm{~S}<7), 5,251(\mathrm{~S} 7-6)$, 4,980 (S7-5), and 4,518 (control) h/cow (SEM 84.6, $P<0.001$ ). The difference in time at pasture between grazing systems occurred mainly between February and June and, to a lesser extent, during October and November of each grazing season (Figure 3).

\section{Treading Damage}

Grazing system affected $(P<0.001)$ hoofprint depth and soil surface deformation (Figure 4 ). We found close relationships between annual number of hours at pasture per cow and (1) mean annual hoofprint depth and (2) mean annual soil surface deformation. These relationships were improved with the addition of a quadratic term $(P<0.05)$, indicating a declining influ- ence of time at pasture on treading damage (Figure 4). Within individual grazing events in all grazing systems, the strongest correlation between treading damage and soil moisture status was between VSMC and hoofprint depth in spring (Table 4). At grazing events where VSMC was between 0.7 and 0.5 , restricting access to 8 $\mathrm{h} / \mathrm{d}$ lowered soil surface deformation $(\mathrm{cm} / \mathrm{m}): 14.5$ with 8-h access compared with 16.9 with 22-h access (SEM $0.66, P<0.01)$. It had no effect on hoofprint depth $(\mathrm{cm}): 3.51$ with 8 -h access compared with 3.91 with 22-h access (SEM 0.20, $P=0.13$ ).

\section{Pasture Production and Nutritive Value of Pasture and Silage, and Feed Intake}

Averaged over the $3 \mathrm{yr}$ of the study, annual pasture production was not affected by grazing system (mean $14.8 \pm 0.97 \mathrm{t}$ of $\mathrm{OM} / \mathrm{ha}, P=0.76)$. The control had more pasture mass harvested as silage than the other 3 systems (Table 5). The grazed pasture on the control system had lower $(P<0.05)$ NDF (Table 5$)$. We detected no difference in $\mathrm{CP}$ or $\mathrm{OM}$ digestibility of the grazed pasture between the systems. Likewise, no differences were detectable in the nutritive value of the silages fed to the herds on each system (Table 5). The ash content of the silages averaged $84 \pm 7.1 \mathrm{~g} / \mathrm{kg}$ of DM.

Cows on the control system consumed on average $628 \mathrm{~kg}$ of $\mathrm{DM} /$ cow more $(P<0.001)$ silage per year

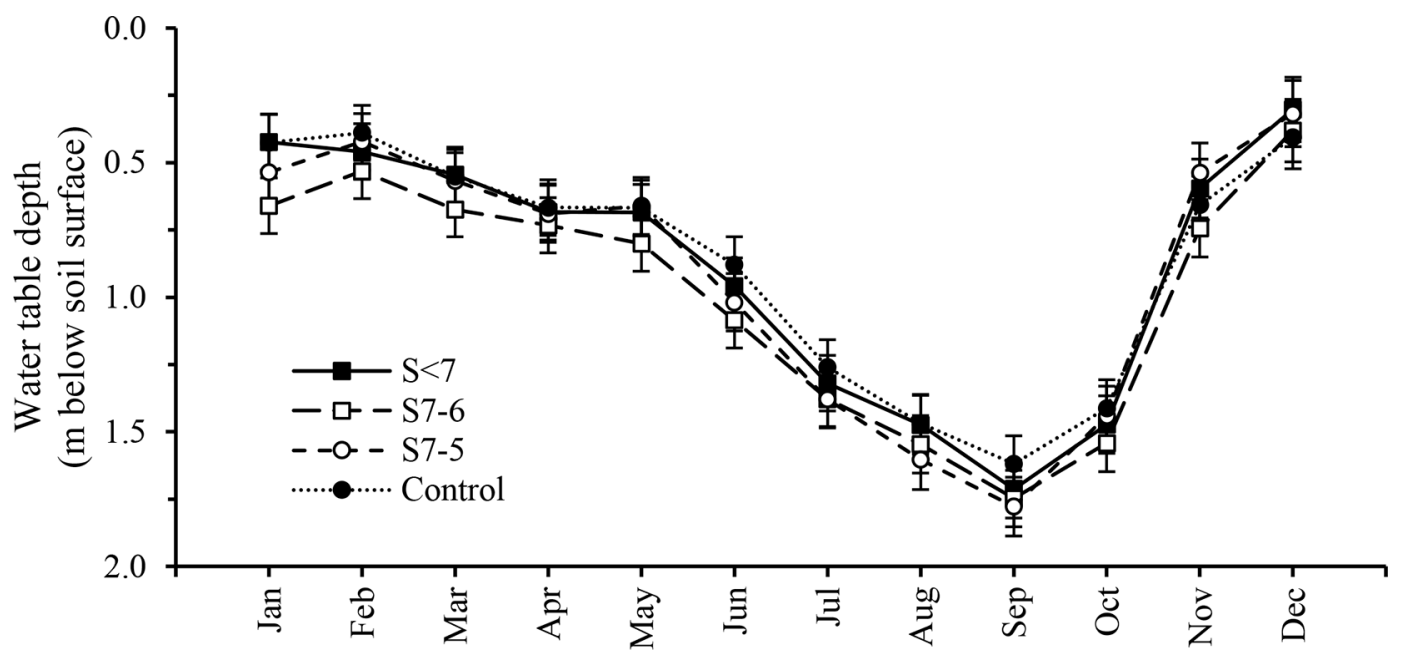

Figure 2. Three-year mean water table depth ( $\mathrm{m}$ below soil surface) per month in the 4 grazing systems $(\mathrm{S}<7, \mathrm{~S} 7-6, \mathrm{~S} 7-5$, and control). Grazing systems: control $=$ cows were housed at VSMC $>0.5$ and otherwise allowed $22 \mathrm{~h} / \mathrm{d}$ access to pasture; $\mathrm{S}<7$ : cows were housed on days with VSMC $>0.7$ and otherwise allowed $22 \mathrm{~h} / \mathrm{d}$ access to pasture; $\mathrm{S} 7-6=$ cows were housed at VSMC $>0.7$ and allowed $8 \mathrm{~h} / \mathrm{d}$ access to pasture at VSMC between 0.7 and 0.6 and $22 \mathrm{~h} / \mathrm{d}$ access at VSMC $\leq 0.6 ; \mathrm{S} 7-5=$ cows were housed at VSMC $>0.7$ and allowed $8 \mathrm{~h} / \mathrm{d}$ access to pasture at VSMC between 0.7 and 0.5 and $22 \mathrm{~h} / \mathrm{d}$ access at VSMC $\leq 0.5$ (see Table 1 for further description). Error bars show SE of the interaction between month by system mean $(P=0.91)$. 


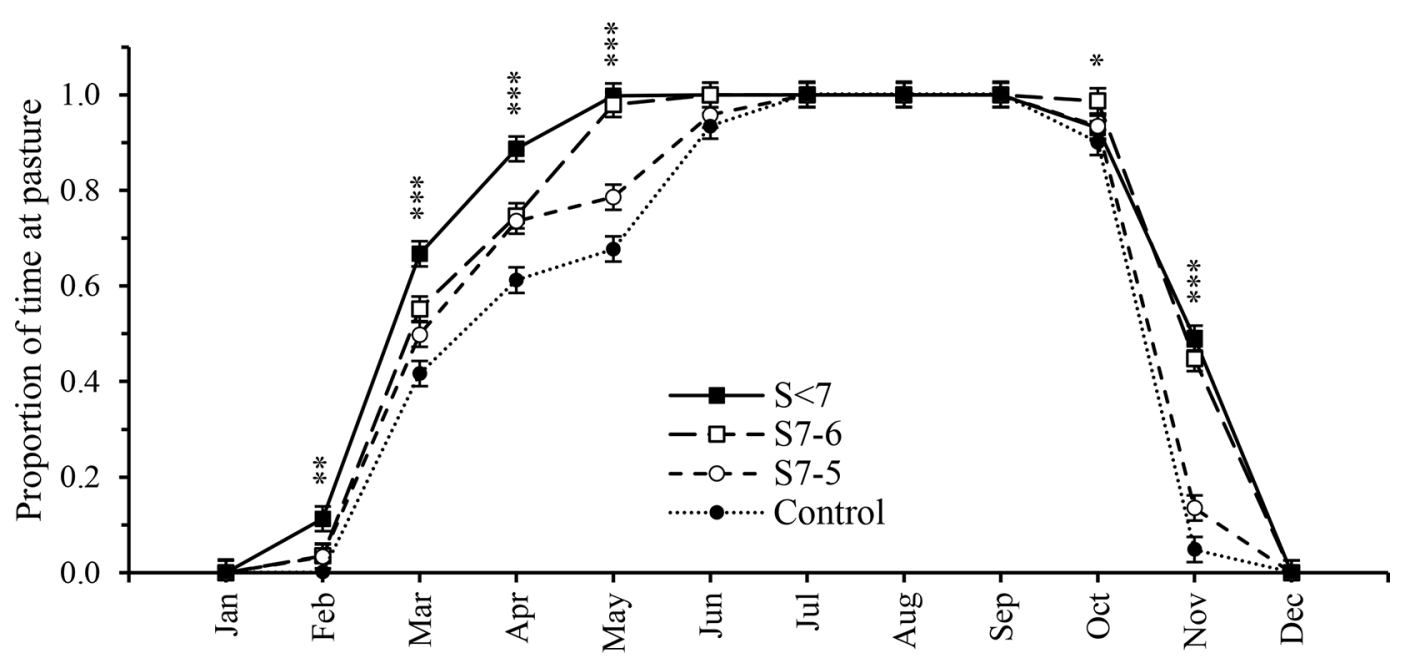

Figure 3. Proportion of total available time per month $(22 \mathrm{~h}$ per each day of the month) that was spent at pasture in the 4 grazing systems $(\mathrm{S}<7, \mathrm{~S} 7-6$, S7-5, and control) during the experiment. Grazing systems: control $=$ cows were housed at VSMC $>0.5$ and otherwise allowed 22 $\mathrm{h} / \mathrm{d}$ access to pasture; $\mathrm{S}<7$ : cows were housed on days with VSMC $>0.7$ and otherwise allowed $22 \mathrm{~h} / \mathrm{d}$ access to pasture; $\mathrm{S} 7-6=$ cows were housed at VSMC $>0.7$ and allowed $8 \mathrm{~h} / \mathrm{d}$ access to pasture at VSMC between 0.7 and 0.6 and $22 \mathrm{~h} / \mathrm{d}$ access at VSMC $\leq 0.6$; S7-5 = cows were housed at VSMC $>0.7$ and allowed $8 \mathrm{~h} / \mathrm{d}$ access to pasture at VSMC between 0.7 and 0.5 and $22 \mathrm{~h} / \mathrm{d}$ access at VSMC $\leq 0.5$ (see Table 1 for further description). Error bars show SE of the interaction between month by system mean $(P<0.001)$. Differences between grazing systems within a month are indicated with ${ }^{*} P<0.05,{ }^{* *} P<0.01$, and ${ }^{* * *} P<0.001$.

compared with cows on $\mathrm{S}<7, \mathrm{~S} 7-6$, and $\mathrm{S} 7-5$, which consumed a mean of $1,145 \pm 51.0 \mathrm{~kg}$ of $\mathrm{DM} /$ cow (Table $5)$. The difference in silage intake by the control compared with the other systems was mainly during the period from January to May (400 $\mathrm{kg}$ of $\mathrm{DM} / \mathrm{cow}$ ) and, to a lesser extent, during the period between September and December, when the difference was $217 \mathrm{~kg}$ of $\mathrm{DM} /$ cow (Table 5 ). Control had lower pasture intake of $2,858 \mathrm{~kg}$ of DM/cow compared with $\mathrm{S}<7(3,675), \mathrm{S} 7-6$ $(3,643)$, and $\mathrm{S} 7-5(3,561 \mathrm{~kg}$ of DM/cow, SEM 140.7, $P$ $<0.001)$. Annual concentrate intake was not different between systems (548 $\pm 30.3 \mathrm{~kg}$ of DM/cow, $P=0.74)$.

\section{Milk Production, BCS, and BW}

Annual milk solids production was lowest $(P<0.05)$ in the control herd, although annual milk yield was not different between systems (Table 6). We also found lower $(P<0.01)$ annual average milk protein content in control $(37.7 \mathrm{~g} / \mathrm{kg})$ compared with the other systems (mean of $38.6 \mathrm{~g} / \mathrm{kg}$ ). A significant interaction occurred $(P<0.01)$ between grazing system and week of lactation for daily milk solids yield: it was lower in control compared with the other systems during the first $14 \mathrm{wk}$ of lactation (Figure 5).

No difference was detectable in the BW of cows on each of the systems during the study (Table 6). The cows on $\mathrm{S}<7$ had a higher $(P<0.01)$ mean BCS than the cows in each of the other systems, which were not different from each other (Table 6).

\section{Economic Analysis}

The total annual requirement for labor increased from 3,338 h $(\mathrm{S}<7)$ to $3,368 \mathrm{~h}(\mathrm{~S} 7-6), 3,389 \mathrm{~h}(\mathrm{~S} 7-5)$, and $3,445 \mathrm{~h}$ (control), which is equivalent to annual labor requirements of $26.7,26.9,27.1$, and $27.5 \mathrm{~h} / \mathrm{cow}$, respectively. As a result, labor costs increased $(P<$ 0.001 ) with less time spent at pasture (Table 7$)$. Net profit was lowest $(P<0.001)$ in the control system, due to a combination of higher costs and lower milk sales compared with the other 3 systems, which were not different from each other. The difference in net profit between control and $\mathrm{S}<7$ comprised lower milk sales (0.26 of the difference in net profit), higher labor costs (0.10), and higher variable costs (0.64) in the control system. Higher variable costs in control compared with $\mathrm{S}<7$ were mainly related to silage (higher silage-making costs and lower silage sales; 0.79 of the difference in variable costs) and, to a lesser extent, by higher slurry handling costs (0.21). Numerically higher total costs of production in S7-6 and $\mathrm{S} 7-5$ compared with $\mathrm{S}<7$ were caused by an increase in contracting costs for slurry spreading (0.37 and 0.36) and higher requirements for labor $(0.63$ and 0.64 of increase in total costs from $\mathrm{S}<7$ to S7-6 and S7-5, respectively). Over the 3 yr of the 
Table 4. Pearson correlation coefficient (r) between measures of treading damage (hoofprint depth and soil surface deformation) and measures of soil moisture status at the time of grazing [volumetric soil moisture content (VSMC) and water table depth (WTD)] in spring (March-May), summer (June-August), autumn (SeptemberNovember) and annually (Year)

\begin{tabular}{llcr}
\hline Measurement & Period & VSMC & WTD \\
\hline Hoofprint depth & Spring & $0.41^{* *}$ & -0.01 \\
& Summer & -0.14 & -0.29 \\
& Autumn & 0.17 & 0.03 \\
Soil surface deformation & Year & $0.27^{* * *}$ & -0.09 \\
& Spring & 0.17 & 0.09 \\
& Summer & -0.25 & -0.30 \\
& Autumn & 0.20 & -0.12 \\
& Year & 0.15 & -0.07 \\
\hline
\end{tabular}

${ }^{* *} P<0.01 ;{ }^{* * *} P<0.001$.

study, variable costs, total costs, gross output, and net profit were not significantly different between $\mathrm{S} 7-5$, S7-6, and $\mathrm{S}<7(P<0.01$, Table 7$)$.

\section{DISCUSSION}

\section{Effects of Soil Moisture and Time at Pasture on Treading Damage}

Many previous studies have shown that higher soil moisture lowers penetration resistance, making soils more susceptible to treading damage by grazing dairy cows (Drewry et al., 2008; Houlbrooke et al., 2009; Kerebel et al., 2013; Phelan et al., 2013), similar to the results observed in the present study. Hoofprint depth was most closely related to VSMC in spring; soil moisture was relatively high in each of the springs during this study. Progressively shorter rotation lengths, as pasture growth rates increased during spring, made spring a high-risk period for repeated treading damage, similar to results reported by Phelan et al. (2013). During the autumns of the present study, rainfall was below average and VSMC was relatively low compared with earlier studies at this site (Phelan et al., 2013; Tuohy et al., 2015), which explains the lack of correlation between hoofprint depth and VSMC during the autumns of the present study. Phelan et al. (2013) reported that hoofprint depth followed the same monthly trend as VSMC during the grazing season. In contrast, the trend in soil surface deformation during the autumn did not follow these trends. This is somewhat similar to what was recorded in the present study.

The correlation coefficients between hoofprint depth or soil surface deformation and VSMC at individual grazing events were relatively low in the present study. One factor contributing to this was the location of the VSMC measurement, which was centrally measured at the farm weather station. The objective was to test an

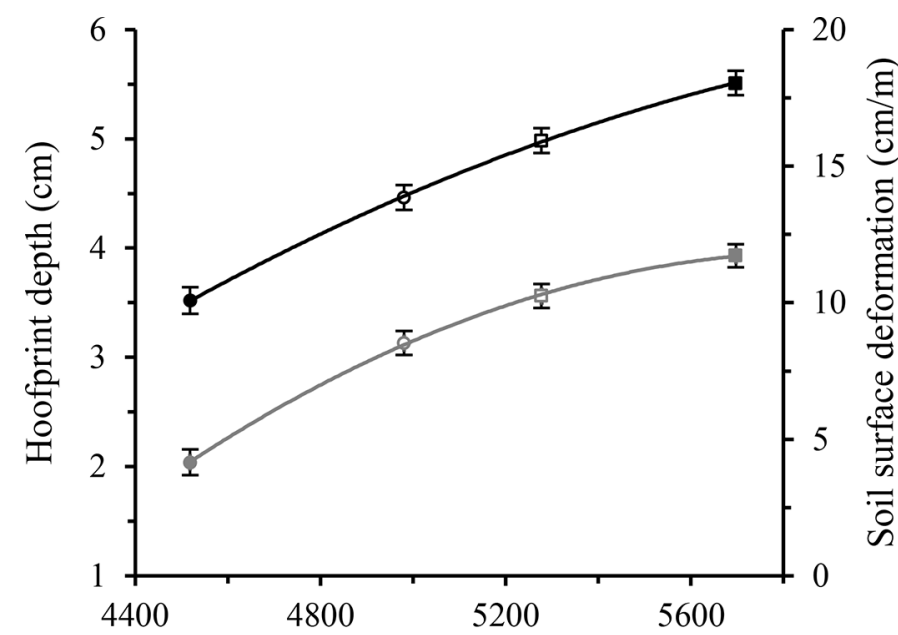

Time at pasture (hours/cow per year)

Figure 4. Effects of and relationship between mean annual time at pasture per cow and mean annual (1) soil surface deformation $(\mathrm{cm} / \mathrm{m}$, black line; $\left.\mathrm{y}=-2.41 \times 10^{-6} \mathrm{x}^{2}+0.03 \mathrm{x}-82.8 ; \mathrm{R}^{2}=0.99 ; P=0.03\right)$ and (2) hoofprint depth (cm, gray line; $\mathrm{y}=-1.03 \times 10^{-6} \mathrm{x}^{2}+0.01 \mathrm{x}$ $\left.-31.7 ; \mathrm{R}^{2}=0.99 ; P=0.003\right)$ in the 4 grazing systems $(\mathrm{S}<7=$ filled square, $\mathrm{S} 7-6=$ empty square, $\mathrm{S} 7-5=$ empty circle, control $=$ filled circle). Error bars show SEM of the grazing system. Grazing systems: control $=$ cows were housed at VSMC $>0.5$ and otherwise allowed 22 $\mathrm{h} / \mathrm{d}$ access to pasture; $\mathrm{S}<7$ : cows were housed on days with VSMC $>0.7$ and otherwise allowed $22 \mathrm{~h} / \mathrm{d}$ access to pasture; $\mathrm{S} 7-6=$ cows were housed at VSMC $>0.7$ and allowed $8 \mathrm{~h} / \mathrm{d}$ access to pasture at VSMC between 0.7 and 0.6 and $22 \mathrm{~h} / \mathrm{d}$ access at VSMC $\leq 0.6 ; \mathrm{S} 7-5=$ cows were housed at VSMC $>0.7$ and allowed $8 \mathrm{~h} / \mathrm{d}$ access to pasture at VSMC between 0.7 and 0.5 and $22 \mathrm{~h} / \mathrm{d}$ access at VSMC $\leq 0.5$ (see Table 1 for further description).

easily adaptable decision support tool that can be stationary on farms, with minimal additional management requirements. The centrally located measurement was a useful decision support for assessing the risk of treading damage when turning cows out to pasture. Governing grazing management based on VSMC effectively lowered treading damage. Nonetheless, natural variations in soil moisture exist between paddocks of the farm, caused by slopes and differences in drainage. Therefore, it is possible that the accuracy of the method could be improved by measuring VSMC on the individual paddocks before a grazing event.

Restricting access time to pasture to $8 \mathrm{~h} / \mathrm{d}$ had a greater effect on soil surface deformation than on hoofprint depth, because it decreased the frequency of soil-hoof interactions but not the depth to which each individual hoofprint penetrated into the soil. In contrast, WTD showed no correlation with soil surface deformation or with hoofprint depth at individual grazing events during the present study. The WTD is an indicator of the underlying moisture status of the subsoil. In late summer, when WTD is typically low, slow-draining soils can still develop a high VSMC in the topsoil over a 
Table 5. Effects of grazing system on annual pasture production and nutritive value of grazed pasture and of silage (mean of 3 yr) and grass silage intake per cow during different times of the year (mean of $3 \mathrm{yr}$ )

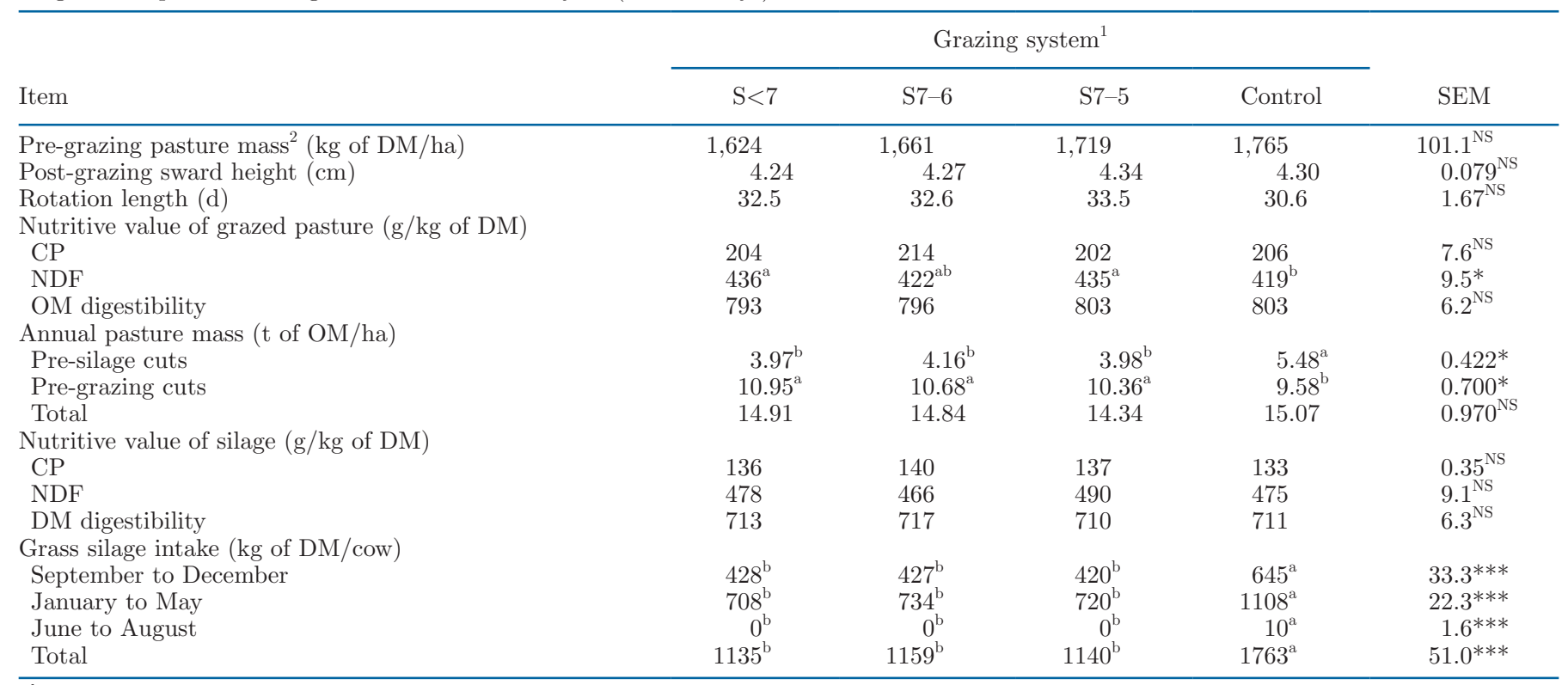

${ }^{\mathrm{a}, \mathrm{b}}$ Mean values in the same row with different superscripts differ between grazing systems $(P<0.05)$.

${ }^{1} \mathrm{~S}<7$ : cows were housed on days with VSMC $>0.7$ and otherwise allowed $22 \mathrm{~h} / \mathrm{d}$ access to pasture; $\mathrm{S} 7-6=$ cows were housed at VSMC $>0.7$ and allowed $8 \mathrm{~h} / \mathrm{d}$ access to pasture at VSMC between 0.7 and 0.6 and $22 \mathrm{~h} / \mathrm{d}$ access at VSMC $\leq 0.6 ; \mathrm{S} 7-5=$ cows were housed at VSMC $>0.7$ and allowed $8 \mathrm{~h} / \mathrm{d}$ access to pasture at VSMC between 0.7 and 0.5 and $22 \mathrm{~h} / \mathrm{d}$ access at VSMC $\leq 0.5$; control $=$ cows were housed at VSMC $>0.5$ and otherwise allowed $22 \mathrm{~h} / \mathrm{d}$ access to pasture (see Table 1 for further description).

${ }^{2} 4 \mathrm{~cm}$ above ground level.

${ }^{*} P<0.05 ;{ }^{* *} P<0.01 ;{ }^{* * *} P<0.001 ;{ }^{\text {NS }} P>0.05$ (not significant).

short timeframe after a high-rainfall event, making the top layers susceptible to treading damage without significantly increasing WTD. Phelan et al. (2013) showed a relationship between mean annual WTD and mean annual soil surface deformation and hoofprint depth in an earlier study at the site, which highlighted the potential of land drainage to lower the susceptibility of soils to treading damage during periods with high WTD. The study of Phelan et al. (2013) took place during 2008 and 2009. The rainfall during the summer

Table 6. Effects of grazing system on 3-yr mean annual milk production and composition, BW, and BCS of dairy cows

\begin{tabular}{lccccc}
\hline & \multicolumn{4}{c}{ Grazing system $^{1}$} \\
\cline { 2 - 5 } Item & $\mathrm{S}<7$ & $\mathrm{~S} 7-6$ & $\mathrm{~S} 7-5$ & Control & \multirow{2}{*}{ SEM } \\
\hline Milk yield $(\mathrm{kg} / \mathrm{cow})$ & 5,998 & 6,047 & 5,906 & 5,839 & $161.8^{\mathrm{NS}}$ \\
Milk solids yield $^{2}(\mathrm{~kg} / \mathrm{cow})$ & $503^{\mathrm{a}}$ & $509^{\mathrm{a}}$ & $496^{\mathrm{ab}}$ & $485^{\mathrm{b}}$ & $14.4^{*}$ \\
Milk fat content $(\mathrm{g} / \mathrm{kg})^{\text {Milk protein content }(\mathrm{g} / \mathrm{kg})}$ & 45.3 & 45.9 & 45.5 & 45.8 & $1.09^{\mathrm{NS}}$ \\
Milk lactose content $(\mathrm{g} / \mathrm{kg})$ & $38.8^{\mathrm{a}}$ & $38.5^{\mathrm{a}}$ & $38.56^{\mathrm{a}}$ & $37.7^{\mathrm{b}}$ & $0.33^{* *}$ \\
Mean BW $(\mathrm{kg} / \mathrm{cow})$ & $48.6^{\mathrm{ab}}$ & $48.6^{\mathrm{ab}}$ & $48.4^{\mathrm{b}}$ & $48.9^{\mathrm{a}}$ & $0.32^{*}$ \\
Mean BCS & 547 & 553 & 544 & 546 & $11.1^{\mathrm{NS}}$ \\
DIM & $3.10^{\mathrm{a}}$ & $3.06^{\mathrm{b}}$ & $3.06^{\mathrm{b}}$ & $3.05^{\mathrm{b}}$ & $0.042^{* *}$ \\
\hline
\end{tabular}

$\overline{a, b}$ Mean values in the same row with different superscripts differ between grazing systems $(P<0.05)$. ${ }^{1} \mathrm{~S}<7$ : cows were housed on days with VSMC $>0.7$ and otherwise allowed $22 \mathrm{~h} / \mathrm{d}$ access to pasture; $\mathrm{S} 7-6=$ cows were housed at VSMC $>0.7$ and allowed $8 \mathrm{~h} / \mathrm{d}$ access to pasture at VSMC between 0.7 and 0.6 and 22 $\mathrm{h} / \mathrm{d}$ access at VSMC $\leq 0.6 ; \mathrm{S} 7-5=$ cows were housed at VSMC $>0.7$ and allowed $8 \mathrm{~h} / \mathrm{d}$ access to pasture at VSMC between 0.7 and 0.5 and $22 \mathrm{~h} / \mathrm{d}$ access at VSMC $\leq 0.5$; control $=$ cows were housed at VSMC $>0.5$ and otherwise allowed $22 \mathrm{~h} / \mathrm{d}$ access to pasture (see Table 1 for further description).

${ }^{2}$ Milk solids yield $=\mathrm{kg}$ of milk fat + protein.

${ }^{*} P<0.05 ;{ }^{* *} P<0.01 ;{ }^{\text {NS }} P>0.05$ (not significant). 


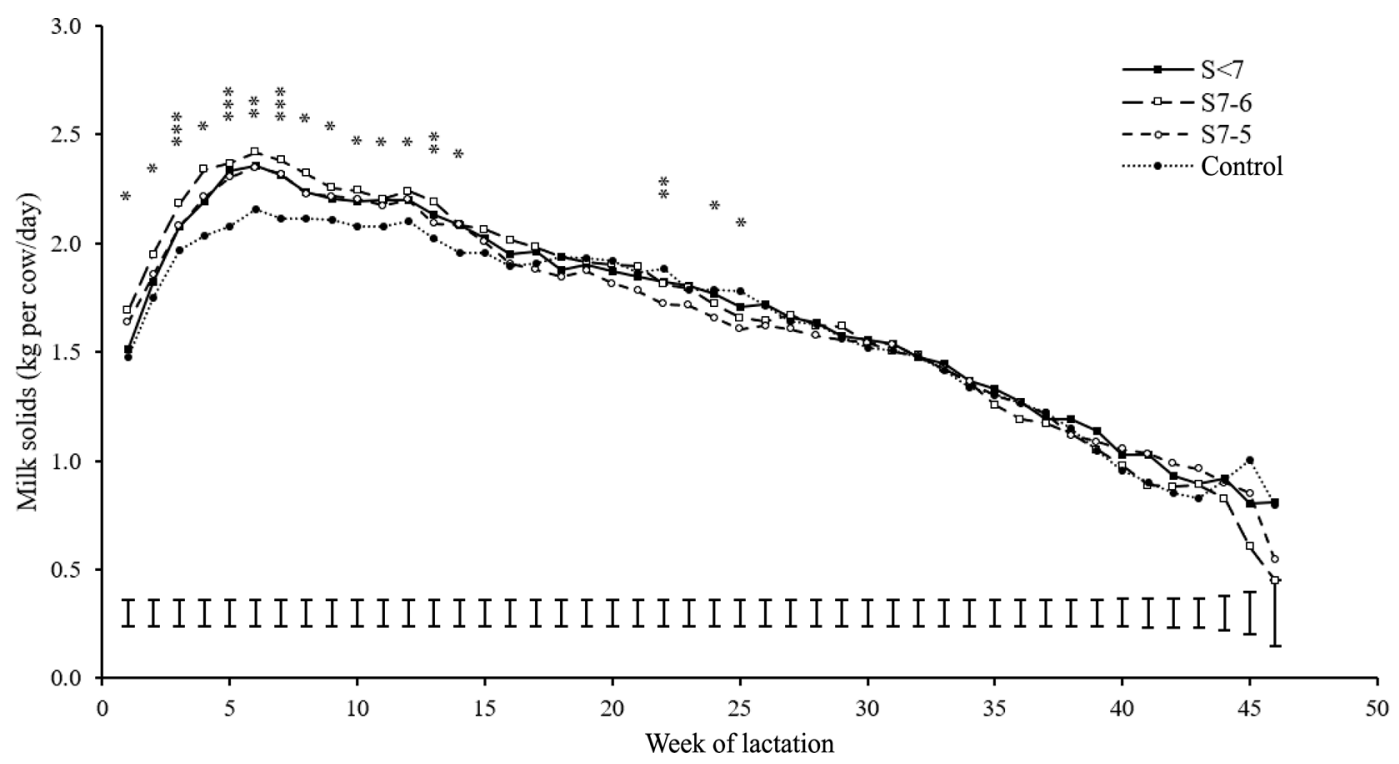

Figure 5. Effects of week of lactation and grazing system $(\mathrm{S}<7, \mathrm{~S} 7-6, \mathrm{~S} 7-5$, and control) on daily milk solids yield (fat + protein, $\mathrm{kg} / \mathrm{cow})$. Grazing systems: control $=$ cows were housed at VSMC $>0.5$ and otherwise allowed $22 \mathrm{~h} / \mathrm{d}$ access to pasture; $\mathrm{S}<7$ : cows were housed on days with VSMC $>0.7$ and otherwise allowed $22 \mathrm{~h} / \mathrm{d}$ access to pasture; S7-6 = cows were housed at VSMC $>0.7$ and allowed $8 \mathrm{~h} / \mathrm{d}$ access to pasture at VSMC between 0.7 and 0.6 and $22 \mathrm{~h} / \mathrm{d}$ access at VSMC $\leq 0.6 ; \mathrm{S} 7-5=$ cows were housed at VSMC $>0.7$ and allowed $8 \mathrm{~h} / \mathrm{d}$ access to pasture at VSMC between 0.7 and 0.5 and $22 \mathrm{~h} / \mathrm{d}$ access at VSMC $\leq 0.5$ (see Table 1 for further description). Error bars show SEM of week of lactation $(P<0.001)$. Differences between grazing systems within week of lactation are indicated with ${ }^{*} P<0.05,{ }^{* *} P<0.01$, and ${ }^{* * *} P<0.001$.

months of these 2 years was significantly higher than average, in contrast to the present study. Nevertheless, the results of the present study demonstrated that, at individual grazing events, WTD did not directly indicate the current moisture status of, and likelihood of damage to, the soil surface to the same extent as VSMC. Additionally, measuring WTD involved the installation of piezometers, making it a more complex and expensive method for measuring soil wetness.

\section{Effect of Grazing System on Pasture Production}

Keeping cows indoors to a greater or lesser extent during periods of wet soil conditions to lower treading

Table 7. Effects of grazing system on annual profitability at a base milk price of $€ 0.29 / \mathrm{L}$

\begin{tabular}{lrrrrr}
\hline & \multicolumn{4}{c}{ Grazing system $^{1}$} \\
\cline { 2 - 4 } Item & $\mathrm{S}<7$ & $\mathrm{~S} 7-6$ & $\mathrm{~S} 7-5$ & Control & \multirow{2}{*}{ SEM } \\
\hline Cows (no.) & 125 & 125 & 125 & 125 \\
Farm size (ha) & 50 & 50 & 50 & 50 & \\
Milk output (kg) & 741,101 & 741,101 & 741,101 & 741,101 & $2,401^{\mathrm{NS}}$ \\
Milk solids output ${ }^{2}(\mathrm{~kg})$ & $62,405^{\mathrm{a}}$ & $62,405^{\mathrm{a}}$ & $62,405^{\mathrm{a}}$ & $61,691^{\mathrm{b}}$ & $732^{* * *}$ \\
Gross output $(€)$ & $282,734^{\mathrm{a}}$ & $282,734^{\mathrm{a}}$ & $282,734^{\mathrm{a}}$ & $278,721^{\mathrm{b}}$ & $3,097^{* * *}$ \\
Variable cost $(€)$ & $89,239^{\mathrm{b}}$ & $90,040^{\mathrm{b}}$ & $90,527^{\mathrm{b}}$ & $99,134^{\mathrm{a}}$ & $1,390^{* *}$ \\
Labor cost $(€)$ & $50,063^{\mathrm{d}}$ & $50,508^{\mathrm{c}}$ & $50,823^{\mathrm{b}}$ & $51,653^{\mathrm{a}}$ & $116^{* * *}$ \\
Fixed costs excluding labor $(€)$ & 42,923 & 42,923 & 42,923 & 42,923 & $28^{\mathrm{NS}}$ \\
Total costs $(€)$ & $182,224^{\mathrm{b}}$ & $183,470^{\mathrm{b}}$ & $184,273^{\mathrm{b}}$ & $193,709^{\mathrm{a}}$ & $1,386^{* *}$ \\
Net profit $(€)$ & $100,510^{\mathrm{a}}$ & $99,264^{\mathrm{a}}$ & $98,461^{\mathrm{a}}$ & $85,011^{\mathrm{b}}$ & $2,335^{* * *}$ \\
Net profit $(€ /$ ha) & $2,010^{\mathrm{a}}$ & $1,985^{\mathrm{a}}$ & $1,969^{\mathrm{a}}$ & $1,700^{\mathrm{b}}$ & $47^{* * *}$ \\
Net profit $(€ /$ cow $)$ & $804^{\mathrm{a}}$ & $794^{\mathrm{a}}$ & $788^{\mathrm{a}}$ & $680^{\mathrm{b}}$ & $19^{* * *}$ \\
\hline
\end{tabular}

${ }^{a-d}$ Mean values in the same row with different superscripts differ between grazing systems $(P<0.05)$.

${ }^{1} \mathrm{~S}<7$ : cows were housed on days with VSMC $>0.7$ and otherwise allowed $22 \mathrm{~h} / \mathrm{d}$ access to pasture; $\mathrm{S} 7-6=$ cows were housed at VSMC $>0.7$ and allowed $8 \mathrm{~h} / \mathrm{d}$ access to pasture at VSMC between 0.7 and 0.6 and 22 $\mathrm{h} / \mathrm{d}$ access at VSMC $\leq 0.6 ; \mathrm{S} 7-5=$ cows were housed at VSMC $>0.7$ and allowed $8 \mathrm{~h} / \mathrm{d}$ access to pasture at VSMC between 0.7 and 0.5 and $22 \mathrm{~h} / \mathrm{d}$ access at VSMC $\leq 0.5$; control $=$ cows were housed at VSMC $>0.5$ and otherwise allowed $22 \mathrm{~h} / \mathrm{d}$ access to pasture (see Table 1 for further description).

${ }^{2}$ Milk solids $=\mathrm{kg}$ of milk fat + protein.

${ }^{* *} P<0.01 ;{ }^{* * *} P<0.001$; ${ }^{\mathrm{NS}} P>0.05$ (not significant). 
damage did not result in differences in annual pasture production between the systems. In 2 plot-scale experiments in New Zealand, Houlbrooke et al. (2009) compared 3-h access to pasture per rotation versus a control treatment (access to pasture for the whole day except milking times). Likewise, Laurenson et al. (2016) compared 8-h versus 21-h access to pasture. Both studies found that restricting access time to pasture under wet soil conditions improved soil physical properties compared with unrestricted access time. However, both studies found no influence on pasture production, which is in agreement with the results of the present study. Previous studies have shown that well-managed perennial ryegrass swards can recover well from single grazing events with intensive treading damage in spring, with no effect on subsequent pasture production (Tuñon et al., 2014). Moreover, soils have innate capacity to recover from treading damage during the grazing season (Drewry, 2006). Hence, it is likely that sward and soil recovery was sufficient to counteract potential negative effects of treading damage on pasture production in the present study. In the systems that had access to pasture at VSMC $>0.5(\mathrm{~S}<7, \mathrm{~S} 7-6$, and $\mathrm{S} 7-5$ ), there were on average 2 grazing events per paddock per year when VSMC was above 0.5. Hence, repeated (one after the other) severe treading damage during wet soil conditions may have occurred only once per paddock per grazing season. Following a modeled evaluation of economic and production benefits of removing dairy cows from wet pastures, Laurenson et al. (2017) suggested that treading damage might not affect pasture production as severely when assessed at system scale over an entire grazing season. This is confirmed by the results of the present study.

Phelan et al. (2013) compared pasture production under 2 intensities of repeated treading damage (moderate and severe) with that from exclusion plots that were protected from treading damage throughout the entire study. Despite higher pasture production from the nondamaged exclusion plots, no difference was detectable in pasture production between the treading treatments. In the present study, treading damage occurred in all 4 grazing systems. It seems that the difference in the severity of treading damage in the present study was not sufficient to have a detectable influence on pasture production. These results also help to explain the absence of a difference between treatments in the study of Tuohy et al. (2015). Although hoofprint depth was greater with heavier Holstein Friesian cows compared with lighter Holstein Friesian $\times$ Jersey crossbred cows, no effect of the higher intensity of treading damage on pasture production was detected (Tuohy et al., 2015).

During the grazing season, VSMC $>0.7$ typically occur only occasionally (on an average of $10 \mathrm{~d}$ between
February and December in the present study). Allowing cows out to pastures with VSMC $<0.7$ encompassed almost the entire growing season. Using VSMC of 0.7 as an upper limit in $\mathrm{S}<7, \mathrm{~S} 7-6$, and $\mathrm{S} 7-5$ may have avoided excessive damage. Hence, the results of this study indicate that grazing with dairy cows might be feasible even above the upper limit of 0.7 VSMC tested in the present study. Further research is required to determine whether a "tipping point" exists, above which treading damage is detrimental to pasture production.

\section{Effects of Grazing System on Feed Intake and Milk Production}

Keeping cows at pasture for longer during the spring and autumn (i.e., operating a grazing system with high risk of treading damage, $\mathrm{S}<7$ ) resulted in more time at pasture, a lower proportion of silage in the diet, higher milk protein content, higher annual milk solids production, and higher body condition score compared with control. Keeping cows indoors for longer required greater silage production under the control system. Silage was typically harvested at higher pasture masses and, hence, a later maturity stage than the grazed pasture throughout this study. Typically, grass plants at later maturity have lower nutritive value compared with younger grass swards at lower pasture masses (Beecher et al., 2015). As a result, the grazed pasture in the present study had higher digestibility and $\mathrm{CP}$ and lower NDF than the silages fed. The nutritive value of silages is further influenced by the weather conditions and management just before harvest and during the ensiling process, and silage typically has lower water-soluble carbohydrate content than grazed pasture because that is the main substrate for the fermentation process (Keady et al., 2013). Fermentation typically also causes an increase in the rapidly soluble components of CP due to proteolysis and deamination processes (Keady et al., 2013).

The relationships between the various aspects of the nutritive value of diets and subsequent dairy cow performance are complex and multifaceted, and were likely to have been influenced by weather conditions, grazing conditions, and grazing or feeding behavior during the present study. The latter aspect was not measured in the present study, but grazing or feeding behavior is known to influence diet selection (Keady et al., 2013) and to be influenced by interactions between cows in a herd, particularly with more limited space per cow in indoor settings (Olmos et al., 2009; Arnott et al., 2017). Indeed, one of the main reasons why cows prefer grazing outdoors is attributed to more space, lower exposure to bullying (aggression between cows), and improved lying and resting time (Arnott et al., 2017). 
Furthermore, although the welfare of the cows was not measured in the present study, the higher BCS of the cows on $\mathrm{S}<7$ compared with the other systems, along with their relatively high milk solids production, indirectly indicates that the welfare of the cows on $\mathrm{S}<7$, although they were outside for longer under wetter soil conditions, was not impaired compared with the cows on the other systems during this study.

The higher nutritive value of grazed pasture compared with the silages fed during this study provides the most evident reason for the higher BCS and milk solids production by the $\mathrm{S}<7$ herd compared with the control herd. Keady et al. (2013) and Mohammed et al. (2009) attributed a lower performance of dairy cows fed grass silage to lower intake of silage compared with cows fed grazed pasture. This was partly attributed to greater capacity for grazing cows to preferentially select and consume the leafy and more easily digestible portions of the grass sward. The higher NDF content of the silages in the present study is also likely to have lowered silage intake (Mohammed et al., 2009). Furthermore, Keady et al. (1996) attributed lower performance of dairy cows fed silage compared with grazed pasture to changes in the nitrogenous components and reduced energy value of volatile fatty acids in silage as energy sources for the rumen microflora. Similar to the present study, lower milk protein content has been reported previously for dairy cows fed silage compared with grazed pasture, particularly when the silage was fed during early lactation (Dillon et al., 2002; Kennedy et al., 2005; Claffey et al., 2020). This was attributed to the lower flow of microbial nitrogen and total amino acid nitrogen for silage compared with grazed pasture (Younge et al., 2004). The lower milk solids production of the control herd compared with the other 3 systems in this study was primarily due to lower annual yield of milk protein.

The decisions to restrict the S7-6 and S7-5 herds to 2 grazing bouts each of $4 \mathrm{~h} / \mathrm{d}$, and not to supplement these cows with silage while off pasture, were based on the recommendations outlined by Kennedy et al. $(2009,2011)$. Cows were grazed to a higher postgrazing height in the present study $(4.3 \mathrm{~cm})$ compared with that of Kennedy et al. (2009; $3.5 \mathrm{~cm})$. Hence, both in terms of allowances of grazing time and of pasture per cow at each grazing bout, it seems that the cows on S7-6 and S7-5 were able to adjust their grazing behavior to ensure intake of grazed pasture similar to that of the cows on S7. This is further evidenced by the lack of difference in milk production between the cows from these herds and the $\mathrm{S}<7$ herd. Previous studies have documented that dairy cows can adapt their grazing behavior (biting rate and DM intake per bite) in response to restricted daily access time to pasture, when no additional feed was offered while off pasture (Gregorini et al., 2009; Kennedy et al., 2009; Clark et al., 2010). In contrast, the cows on S7-6 and S7-5 had lower BCS than cows on S7 during the study, which indicates that the former cows were somewhat more restricted than cows on S7. Body weight was not affected, indicating that this restriction was relatively small. This is in contrast to a study by Pérez-Ramírez et al. (2009), where grazing time was more restricted than the 2 bouts of $4 \mathrm{~h} / \mathrm{d}$ in the present study.

Kennedy et al. (2009) reported that restricting access time of cows to pasture to 2 bouts of $4.5 \mathrm{~h} / \mathrm{d}$ did not significantly affect milk production by cows in midlactation compared with $22 \mathrm{~h} / \mathrm{d}$ access. In contrast, Clark et al. (2010) found that 2 bouts of $4 \mathrm{~h} / \mathrm{d}$ lowered milk yield in early lactation but not in late lactation, compared with $22 \mathrm{~h} / \mathrm{d}$ access to pasture. These were conducted over a shorter timeframe than the present study; for example, the study of Kennedy et al. (2009) was over $31 \mathrm{~d}$, compared with the present study, which encompassed 3 entire lactations. We found no evidence in the present study that milk production of the cows on S7-6 and S7-5 differed from that of the cows on S7 at any stage of lactation.

\section{Effect of Grazing System on Profitability}

A higher proportion of silage in the diet has been found to increase costs of production in pasture-based dairy production (Finneran et al., 2012; Hanrahan et al., 2018). Likewise, in the present study, net profit was lowest in the control system due to a combination of higher costs and lower milk sales. Laurenson et al. (2016) modeled the effects of restricting access of dairy cows to pasture and reported higher costs when cows were taken off compared with turned out to pasture during wet soil conditions. The difference was primarily due to higher feed costs. Operational costs of standoff areas (maintenance and slurry handling) were of less importance. This is similar to the results of the present study, where 0.50 of the total difference in net profit between control and $\mathrm{S}<7$ was caused by higher silage-related costs alone. In contrast, the contribution of higher slurry handling costs to the lower net profit of control compared with $\mathrm{S}<7$ was marginal (0.14). Lower milk sales (0.26) and higher labor costs (0.10) accounted for the remainder of the difference.

We observed no improvements in pasture and milk production by restricting daily pasture access time to 8 h. Both S7-5 and S7-6 were numerically less profitable than $\mathrm{S}<7$, due to higher labor and slurry-related costs. However, the difference in net profit was not significant over the 3 yr of the study. With higher intake of grazed 
pasture and lower feed costs, both S7-5 and S7-6 were more profitable than the control. Similarly, Beukes et al. (2013) concluded in a modeling study that 6- to 8-h access to pasture per day under conditions conducive to treading damage was more profitable than keeping cows indoors completely. The 2 main differences between the present study and previous modeling studies of whole-farm scenarios (Beukes et al., 2013; Laurenson et al., 2016, 2017) are that (1) previous studies used a modeling approach with an assumed decreasing pasture production as a function of stocking density and access time to pasture when animals were turned out during wet soil conditions, and (2) capital costs increased when cows were taken off during wet soil conditions (completely or temporarily). However, those studies were conducted in New Zealand, under the premise that standoff facilities had to be purpose-built for holding cows off pasture. Generally, the studies concluded that potential benefits associated with removing cows from pastures during wet soil conditions were completely or temporarily offset by investment costs in standoff facilities. Under Irish conditions, it is typically the case that housing is available for livestock on dairy farms, along with regulated requirements for minimum slurry storage capacity for the winter period. Hence, there was no need for additional capital investment in the present study.

Laurenson et al. (2016) concluded that a deferred grazing management strategy, similar to the control system in the present study, was not economically viable in New Zealand. In contrast, the control in the present study represented a profitable system of dairy production, albeit less profitable than the other options. Over the $3 \mathrm{yr}$ of the study, no significant difference in net profit occurred when cows had a restricted daily access time to pasture of $8 \mathrm{~h}$ compared with cows allowed 22-h access to pasture. Furthermore, restricted daily access time to pasture increased the complexity of grazing management. Previous studies have indicated that restricting daily access time to pasture can have other benefits, such as decreasing nutrient leaching and manure-derived emissions, as a higher proportion of excreta is captured and can subsequently be mechanically spread more evenly across pastures (Clark et al., 2010; van der Weerden et al., 2017; Christensen et al., 2019).

\section{CONCLUSIONS}

Restricting access time to pasture based on VSMC effectively lowered the severity of treading damage, and, hence, measurements of VSMC provided an objective indicator of the risk of treading damage in this study. Operating a grazing system with low risk of treading damage (control) resulted in lower profit. We found no benefits of keeping cows indoors completely or temporarily during periods with VSMC between 0.5 and 0.7 in terms of pasture or milk production. The results of the present study indicate that the degree of plastic deformation incurred within a whole-farm system is not necessarily aligned with pasture production nor with profitability, because treading damage happened only to small proportions of paddocks on the farm at any one time. This study demonstrated the positive effect of a long grazing season on profitability, albeit when a high degree of treading damage was tolerated at the soil surface over the course of the 3 grazing seasons.

\section{ACKNOWLEDGMENTS}

This research was conducted with the financial support of the Irish Department of Agriculture, Food and the Marine (Dublin, Ireland), Project SOGGYLAND, under RSF-11-151, and by the Walsh Scholarship Programme (Oak Park, Carlow, Ireland). The authors acknowledge the technical input of Kerry Tuffy (University College Dublin, Dublin, Ireland), the farm staff at Teagasc Solohead Research Farm, and the laboratory staff at Teagasc Moorepark. The authors have not stated any conflicts of interest.

\section{REFERENCES}

Arnott, G., C. P. Ferris, and N. E. O'Connell. 2017. Review: Welfare of dairy cows in continuously housed and pasture-based production systems. Animal 11:261-273. https://doi.org/10.1017/ S1751731116001336.

Beecher, M., D. Hennessy, T. Boland, M. McEvoy, M. O'Donovan, and E. Lewis. 2015. The variation in morphology of perennial ryegrass cultivars throughout the grazing season and effects on organic matter digestibility. Grass Forage Sci. 70:19-29. https://doi.org/ $10.1111 /$ gfs.12081.

Beukes, P. C., A. J. Romera, D. A. Clark, D. E. Dalley, M. J. Hedley, D. J. Horne, R. M. Monaghan, and S. Laurenson. 2013. Evaluating the benefits of standing cows off pasture to avoid soil pugging damage in two dairy farming regions of New Zealand. N. Z. J. Agric. Res. 56:224-238. https://doi.org/10.1080/00288233.2013 .822002 .

Christensen, C. L., M. J. Hedley, J. A. Hanly, and D. J. Horne. 2019. Duration-controlled grazing of dairy cows. 2: Nitrogen losses in sub-surface drainage water and surface runoff. N. Z. J. Agric. Res. 62:48-68. https://doi.org/10.1080/00288233.2017.1418396.

Claffey, A., L. Delaby, T. M. Boland, and M. Egan. 2020. Implications of adapting autumn grazing management on spring herbage production - The effect on late lactation milk production and the subsequent response in early lactation animal performance. Livest. Sci. 231:103870. https://doi.org/10.1016/j.livsci.2019.103870.

Clark, C. E. F., K. L. M. McLeod, C. B. Glassey, P. Gregorini, D. A. Costall, K. Betteridge, and J. G. Jago. 2010. Capturing urine while maintaining pasture intake, milk production, and animal welfare of dairy cows in early and late lactation. J. Dairy Sci. 93:2280-2286. https://doi.org/10.3168/jds.2009-2907.

Coulter, S., E. McAuley, T. Donnellan, K. Hanrahan, and J. Loughrey. 2020. Annual SCSI/Teagasc Agricultural Land Market Review \& 
Outlook. Accessed Mar. 10, 2021. https://www.teagasc.ie/media/ website/publications/2020/SCSI-Agri-land-property-report.pdf.

Creighton, P., E. Kennedy, L. Shalloo, T. M. Boland, and M. O' Donovan. 2011. A survey analysis of grassland dairy farming in Ireland, investigating grassland management, technology adoption and sward renewal. Grass Forage Sci. 66:251-264. https://doi.org/10 .1111/j.1365-2494.2011.00784.x.

CSO. 2020. Agricultural Input and Output Absolute Prices. Central Statistics Office, Ireland. Accessed Mar. 1, 2021. https://data.cso .ie/product/OIIAP.

DAFM. 2020. 2020 Nitrates Derogation Terms and Conditions. Department of Agriculture, Food and the Marine. Accessed Jul. 15, 2021. https://www.gov.ie/en/publication/6e44d-2020-nitrates -derogation-terms-and-conditions/.

Dillon, P., S. Crosse, B. O'Brien, and R. W. Mayes. 2002. The effect of forage type and level of concentrate supplementation on the performance of spring-calving dairy cows in early lactation. Grass Forage Sci. 57:212-223. https://doi.org/10.1046/j.1365-2494.2002 .00319.x.

Donnellan, T., B. Moran, J. Lennon, and E. Dillon. 2020. Teagasc National Farm Survey 2019 Results. Teagasc, Agricultural Economics and Farm Surveys Department, Rural Economy Development Programme.

Drewry, J., K. Cameron, and G. Buchan. 2008. Pasture yield and soil physical property responses to soil compaction from treading and grazing-A review. Soil Res. 46:237-256. https://doi.org/10.1071/ SR07125.

Drewry, J. J. 2006. Natural recovery of soil physical properties from treading damage of pastoral soils in New Zealand and Australia: A review. Agric. Ecosyst. Environ. 114:159-169. https://doi.org/ 10.1016/j.agee.2005.11.028.

Edmonson, A. J., I. J. Lean, L. D. Weaver, T. Farver, and G. Webster. 1989. A body condition scoring chart for Holstein dairy cows. J. Dairy Sci. 72:68-78. https://doi.org/10.3168/jds.S0022 -0302(89)79081-0.

FAO. 2015. World Reference Base for Soil Resources 2014. Accessed Jul. 15, 2021. http://www.fao.org/soils-portal/data-hub/soil -classification/world-reference-base/en/.

FCI. 2019. FCI Contracting Charges Guide 2019. Farm and Forestry Contractors in Ireland. Accessed Oct. 15, 2020. https:// 9d54bb03-8960-4a76-80d5-3f66cf06cadd.filesusr.com/ugd/162a95 _d1759440755a4cb59afe79139d609de6.pdf.

Finneran, E., P. Crosson, P. O'Kiely, L. Shalloo, P. D. Forristal, and M. Wallace. 2012. Stochastic simulation of the cost of home-produced feeds for ruminant livestock systems. J. Agric. Sci. 150:123139. https://doi.org/10.1017/S002185961100061X.

Fitzgerald, J. B., A. J. Brereton, and N. M. Holden. 2008. Simulation of the influence of poor soil drainage on grass-based dairy production systems in Ireland. Grass Forage Sci. 63:380-389. https://doi .org/10.1111/j.1365-2494.2008.00637.x.

Geary, U., N. Lopez-Villalobos, D. J. Garrick, and L. Shalloo. 2010. Development and application of a processing model for the Irish dairy industry. J. Dairy Sci. 93:5091-5100. https://doi.org/10 $.3168 /$ jds.2010-3487.

Gregorini, P., C. E. F. Clark, J. G. Jago, C. B. Glassey, K. L. M. McLeod, and A. J. Romera. 2009. Restricting time at pasture: Effects on dairy cow herbage intake, foraging behavior, hungerrelated hormones, and metabolite concentration during the first grazing session. J. Dairy Sci. 92:4572-4580. https://doi.org/10 $.3168 /$ jds.2009-2322.

Hanrahan, L., N. McHugh, T. Hennessy, B. Moran, R. Kearney, M. Wallace, and L. Shalloo. 2018. Factors associated with profitability in pasture-based systems of milk production. J. Dairy Sci. 101:5474-5485. https://doi.org/10.3168/jds.2017-13223.

Houlbrooke, D. J., J. J. Drewry, R. M. Monaghan, R. J. Paton, L. C. Smith, and R. P. Littlejohn. 2009. Grazing strategies to protect soil physical properties and maximise pasture yield on a Southland dairy farm. N. Z. J. Agric. Res. 52:323-336. https://doi.org/10 $.1080 / 00288230909510517$.

Humphreys, J., E. Mihailescu, and I. A. Casey. 2012. An economic comparison of systems of dairy production based on N-fertilized grass and grass-white clover grassland in a moist maritime environment. Grass Forage Sci. 67:519-525. https://doi.org/10.1111/j .1365-2494.2012.00871.x.

Jarrige, R. 1989. Ruminant Nutrition: Recommended Allowances and Feed Tables. John Libbey Eurotext.

Jarrige, R., C. Demarquilly, J. P. Dulphy, A. Hoden, J. Robelin, C. Beranger, Y. Geay, M. Journet, C. Malterre, D. Micol, and M. Petit. 1986. The INRA "fill unit" system for predicting the voluntary intake of forage-based diets in ruminants: A review. J. Anim. Sci. 63:1737-1758. https://doi.org/10.2527/jas1986.6361737x.

Keady, T., S. Hanrahan, C. Marley, and N. D. Scollan. 2013. Production and utilization of ensiled forages by beef cattle, dairy cows, pregnant ewes and finishing lambs - A review. Agric. Food Sci 22:70-92. https://doi.org/10.23986/afsci.6852.

Keady, T. W. J., J. J. Murphy, and D. Harrington. 1996. The effects of ensiling on dry-matter intake and milk production by lactating dairy cattle given forage as the sole feed. Grass Forage Sci 51:131-141. https://doi.org/10.1111/j.1365-2494.1996.tb02047.x.

Kennedy, E., J. Curran, B. Mayes, M. McEvoy, J. Murphy, and M. O'Donovan. 2011. Restricting dairy cow access time to pasture in early lactation: The effects on milk production, grazing behaviour and dry matter intake. Animal 5:1805-1813. https://doi.org/10 $.1017 /$ S1751731111000826.

Kennedy, E., M. McEvoy, J. P. Murphy, and M. O'Donovan. 2009. Effect of restricted access time to pasture on dairy cow milk production, grazing behavior, and dry matter intake. J. Dairy Sci. 92:168-176. https://doi.org/10.3168/jds.2008-1091.

Kennedy, E., M. O'Donovan, J. P. Murphy, L. Delaby, and F. O'Mara. 2005. Effects of grass pasture and concentrate-based feeding systems for spring-calving dairy cows in early spring on performance during lactation. Grass Forage Sci. 60:310-318. https://doi.org/10 $.1111 / \mathrm{j} .1365-2494.2005 .00481 . x$.

Kennedy, J., D. Carty, J. McCarthy, E. Kennedy, and M. O'Donovan. 2016. Grazing Guide 2. The Irish Farmers Journal, Teagasc.

Kerebel, A., R. Cassidy, P. Jordan, and N. M. Holden. 2013. Soil moisture deficit as a predictor of the trend in soil water status of grass fields. Soil Use Manage. 29:419-431. https://doi.org/10 .1111 sum. 12054

Läpple, D., T. Hennessy, and M. O'Donovan. 2012. Extended grazing: a detailed analysis of Irish dairy farms. J. Dairy Sci. 95:188-195. https://doi.org/10.3168/jds.2011-4512.

Laurenson, S., D. J. Houlbrooke, and P. C. Beukes. 2016. Assessing the production and economic benefits from preventing cows grazing on wet soils in New Zealand. J. Sci. Food Agric. 96:4584-4593. https: //doi.org/10.1002/jsfa.7676.

Laurenson, S., T. J. van der Weerden, P. C. Beukes, and I. Vogeler. 2017. Evaluating the economic and production benefit of removing dairy cows from pastures in response to wet soil conditions. N. Z. J. Agric. Res. 60:223-244. https://doi.org/10.1080/00288233.2017 .1298630 .

Mohammed, R., C. S. Stanton, J. J. Kennelly, J. K. G. Kramer, J. F. Mee, D. R. Glimm, M. O’Donovan, and J. J. Murphy. 2009. Grazing cows are more efficient than zero-grazed and grass silage-fed cows in milk rumenic acid production. J. Dairy Sci. 92:3874-3893. https://doi.org/10.3168/jds.2008-1613.

Morgan, D. J., G. Stakelum, and J. Dwyer. 1989. Modified neutral detergent cellulase digestibility procedure for use with the 'Fibertec' system. Ir. J. Agric. Food Res. 28:91-92.

O'Mara, F. 1996. A net energy system for cattle and sheep. PhD Diss. Department of Animal Science and Production, University College Dublin, Ireland

Olmos, G., L. Boyle, A. Hanlon, J. Patton, J. J. Murphy, and J. F. Mee. 2009. Hoof disorders, locomotion ability and lying times of cubicle-housed compared to pasture-based dairy cows. Livest. Sci. 125:199-207. https://doi.org/10.1016/j.livsci.2009.04.009.

Pérez-Ramírez, E., J. L. Peyraud, and R. Delagarde. 2009. Restricting daily time at pasture at low and high pasture allowance: Effects on pasture intake and behavioral adaptation of lactating dairy cows. J. Dairy Sci. 92:3331-3340. https://doi.org/10.3168/jds.2008 $-1951$. 
Phelan, P., B. Keogh, I. A. Casey, M. Necpalova, and J. Humphreys. 2013. The effects of treading by dairy cows on soil properties and herbage production for three white clover-based grazing systems on a clay loam soil. Grass Forage Sci. 68:548-563. https://doi.org/ $10.1111 /$ gfs.12014.

Pietola, L., R. Horn, and M. Yli-Halla. 2005. Effects of trampling by cattle on the hydraulic and mechanical properties of soil. Soil Tillage Res. 82:99-108. https://doi.org/10.1016/j.still.2004.08.004.

Schulte, R. P., J. Diamond, K. Finkele, N. M. Holden, and A. J. Brereton. 2005. Predicting the soil moisture conditions of Irish grasslands. Ir. J. Agric. Food Res. 44:95-110.

Shalloo, L., P. Dillon, J. O'Loughlin, M. Rath, and M. Wallace. 2004. Comparison of a pasture-based system of milk production on a high rainfall, heavy-clay soil with that on a lower rainfall, freedraining soil. Grass Forage Sci. 59:157-168. https://doi.org/10 .1111/j.1365-2494.2004.00415.x.

Teagasc. 2013a. Guidelines for the Contract Rearing of Replacement Heifers. Accessed Sep. 15, 2020. https:/ /www.teagasc.ie/media/website/ publications/2013/GuidelinesContractRearingReplacementHeifers .pdf.

Teagasc. 2013b. Management Data for Farm Planning. Teagasc.

Tuñon, G., M. O'Donovan, N. Lopez Villalobos, D. Hennessy, P Kemp, and E. Kennedy. 2014. Spring and autumn animal treading effects on pre-grazing herbage mass and tiller density on two contrasting pasture types in Ireland. Grass Forage Sci. 69:502-513. https://doi.org/10.1111/gfs.12055.
Tuohy, P., O. Fenton, N. M. Holden, and J. Humphreys. 2015. The effects of treading by two breeds of dairy cow with different live weights on soil physical properties, poaching damage and herbage production on a poorly drained clay-loam soil. J. Agric. Sci. 153:1424-1436. https://doi.org/10.1017/S0021859614001099.

van der Weerden, T. J., S. Laurenson, I. Vogeler, P. C. Beukes, S. M. Thomas, R. M. Rees, C. F. E. Topp, G. Lanigan, and C. A. M. de Klein. 2017. Mitigating nitrous oxide and manure-derived methane emissions by removing cows in response to wet soil conditions. $\mathrm{Ag}$ ric. Syst. 156:126-138. https://doi.org/10.1016/j.agsy.2017.06.010.

Van Soest, P. J. 1990. Use of detergents in the analysis of fibrous feeds. II. A rapid method for the determination of fiber and lignin. J. Assoc. Off. Anal. Chem. 73:491-497. https://doi.org/10.1093/ jaoac/73.4.491.

Younge, B. A., J. J. Murphy, and M. Rath. 2004. Nutrient metabolism in the rumen and milk production in cows fed on grass-silage and fresh grass based diets. Livest. Prod. Sci. 88:43-54. https://doi .org/10.1016/j.livprodsci.2003.11.003.

\section{ORCIDS}

F. Fenger (๑) https://orcid.org/0000-0002-2770-9816

I. A. Casey ๑ https://orcid.org/0000-0002-6084-4972 